\title{
Bioactive Compounds in Anti-Diabetic Plants: From Herbal Medicine to Modern Drug Discovery
}

\author{
Ngan Tran ${ }^{1}$, Bao Pham ${ }^{2}$ and Ly Le ${ }^{1, *(1)}$ \\ 1 School of Biotechnology, International University-Vietnam National University, \\ Ho Chi Minh City 721400, Vietnam; kimnganchemistry@gmail.com \\ 2 Information Science Faculty, Saigon University, Ho Chi Minh City 711000, Vietnam; ptbao2005@gmail.com \\ * Correspondence: ly.le@hcmiu.edu.vn
}

Received: 21 July 2020; Accepted: 26 August 2020; Published: 28 August 2020

\begin{abstract}
Natural products, including organisms (plants, animals, or microorganisms) have been shown to possess health benefits for animals and humans. According to the estimation of the World Health Organization, in developing countries, $80 \%$ of the population has still depended on traditional medicines or folk medicines which are mostly prepared from the plant for prevention or treatment diseases. Traditional medicine from plant extracts has proved to be more affordable, clinically effective and relatively less adverse effects than modern drugs. Literature shows that the attention on the application of phytochemical constituents of medicinal plants in the pharmaceutical industry has increased significantly. Plant-derived secondary metabolites are small molecules or macromolecules biosynthesized in plants including steroids, alkaloids, phenolic, lignans, carbohydrates and glycosides, etc. that possess a diversity of biological properties beneficial to humans, such as their antiallergic, anticancer, antimicrobial, anti-inflammatory, antidiabetic and antioxidant activities Diabetes mellitus is a chronic disease result of metabolic disorders in pancreas $\beta$-cells that have hyperglycemia. Hyperglycemia can be caused by a deficiency of insulin production by pancreatic (Type 1 diabetes mellitus) or insufficiency of insulin production in the face of insulin resistance (Type 2 diabetes mellitus). The current medications of diabetes mellitus focus on controlling and lowering blood glucose levels in the vessel to a normal level. However, most modern drugs have many side effects causing some serious medical problems during a period of treating. Therefore, traditional medicines have been used for a long time and play an important role as alternative medicines. Moreover, during the past few years, some of the new bioactive drugs isolated from plants showed antidiabetic activity with more efficacy than oral hypoglycemic agents used in clinical therapy. Traditional medicine performed a good clinical practice and is showing a bright future in the therapy of diabetes mellitus. World Health Organization has pointed out this prevention of diabetes and its complications is not only a major challenge for the future, but essential if health for all is to be attained. Therefore, this paper briefly reviews active compounds, and pharmacological effects of some popular plants which have been widely used in diabetic treatment. Morphological data from V-herb database of each species was also included for plant identification.
\end{abstract}

Keywords: diabetes mellitus; medicinal plants; herb; bioactive compound

\section{Introduction}

Diabetes mellitus (DM) is a metabolic disorder of multiple causes characterized by chronic hyperglycemia with disturbances of carbohydrate, fat and protein metabolism resulting from defects in insulin secretion, insulin action, or both. The effects of diabetes mellitus include long-term damage, dysfunction, and failure of various organs [1]. Diabetes mellitus is divided into three main types [1-5]. Type 1 diabetes (insulin-dependent diabetes mellitus) is an autoimmune disorder developing when 
insulin-producing cells of the pancreas in the body have been destroyed and the pancreas produces little or no insulin. A person who has type $1 \mathrm{DM}$ must take insulin daily to live. It develops most often in children and young adults. Type 2 diabetes has also been known as another term "insulin-independent diabetes mellitus" which accounted for more than $90 \%$ of diagnosed cases of DM in adults. It is a diagnosis in which the pancreas produces enough insulin but the body cannot use the insulin effectively, a condition called insulin resistance. Gestational diabetes mellitus (GDM) is a degree of glucose intolerance with onset or first recognition in the second or third trimester of the period of pregnancy. GDM is caused by the hormone of pregnancy or a shortage of insulin. GDM is one of the most popular disorders of metabolism during pregnancy.

Hyperglycemia causes damage to eyes, kidneys, nerves, heart and blood vessels [6]. According to the ninth edition 2019 of the International Diabetes Federation (IDF) Diabetes Atlas released by the IDF, as of 2019, the total adult population in the age group of 20-79 years stands at 463 million who live with diabetes, which is set to increase to 578 million by 2030 (Figure 1) [7]. There is one patient who dies of diabetes mellitus every $6 \mathrm{~s}$, this rate is higher than death rates from human immunodeficiency virus (HIV) (1.5 million), tuberculosis (1.5 million) and malaria (0.6 million), combined [8-10].

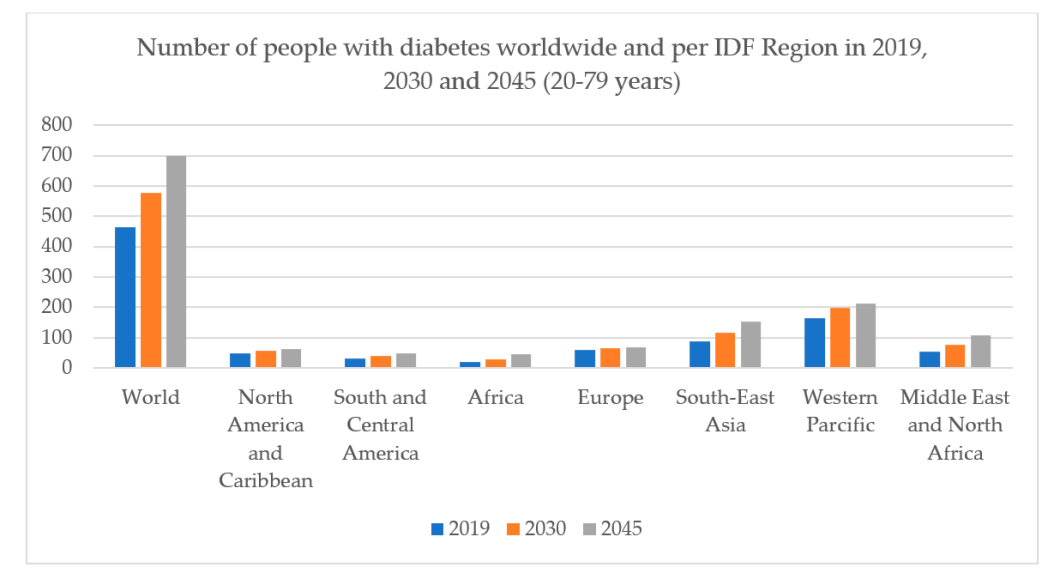

Figure 1. Number of people with diabetes worldwide and per International Diabetes Federation (IDF) region.

Following the Statistics of International Diabetes Federation in 2019 [7], the total adult population in the age group of 20-79 years stands at 463 million live with diabetes, which may increase to 578 million by 2030. Among them, in 2019, 373.9 million adults aged $20-79$ years worldwide, $7.5 \%$ of the adult population, are estimated to have impaired glucose tolerance. Most adults with impaired glucose tolerance are under the age of 50 years (180.0 million- $48.1 \%)$. The estimated prevalence of diabetes in men aged 20-79 years is slightly higher than in women (9.6\% vs $9.0 \%)$. The prevalence of diabetes is expected to increase in both men and women from 2019 to 2030 and 2045 (Figure 2). All around the world, there are top 10 countries that have numbers of people with diabetes, including China, the USA, Indonesia, India, Brazil, Mexico, Japan, Pakistan, Thailand, and Nigeria. Although the risks of GDM with pregnant women have been recognized clearly, there is uncertainty that the treatment reduces and controls blood glucose level of women during pregnancy could decrease those risks or not. Moreover, GDM extends to increase the risk for the development of type 2 DM after giving birth. Nowadays, diabetes mellitus has risen along with rapid cultural and social changes, such as aging, population, less physical activities, dietary, and so on. The cost associate with diabetes includes increasing health services, an economic burden. 


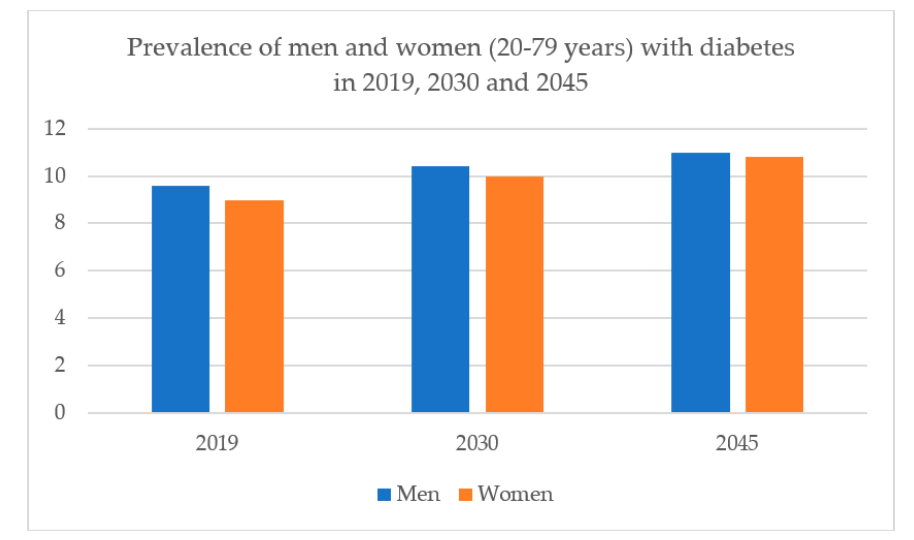

Figure 2. Prevalence of men and women (20-79 years) with diabetes in 2019, 2030 and 2045.

\section{Management of Diabetes Mellitus}

Understanding the pathogenesis of diabetes mellitus is extremely important in treatment. The American Diabetes Association has recommended that the purpose of glycemic control includes a pre-prandial blood glucose level of 80 to $120 \mathrm{mg} / \mathrm{dL}$ ( 4.4 to $6.7 \mathrm{mmol} / \mathrm{L}$ ), a bedtime blood glucose level of 100 to $140 \mathrm{mg} / \mathrm{dL}$ (5.6 to $7.8 \mathrm{mmol} / \mathrm{L}$ ), and an HbA1c level of less than 7\% [2,11]. Healthy eating, physical activity, and weight control are the center of any therapeutic program for patients in DM [12]. These lifestyle modifications not only lower blood glucose levels in the body, but also, they ameliorate many risk factors for cardiovascular disease, and help weightloss. However, most patients cannot have a good lifestyle [13], so patients must depend on medications for treatment.

The present treatment of DM is focused on controlling and lowering blood glucose levels in the vessel to a normal level [11]. The mechanisms of both modern medicines and traditional medicines to lower blood glucose concentration are: (1) to stimulate beta-cell of the pancreatic islet to release more insulin; (2) inhibit the action of hormones which increases blood glucose concentration; (3) increase the sensitivity of insulin receptor site; (4) inhibit hydrolysis of glycogen in liver; (5) enhance the use of glucose in tissues and organ [14-16].

Currently, there are six main classes of modern medicines used all over the world for controlling blood glucose levels and two classes of injections [12]. The tablets are known as biguanides (metformin), sulfonylureas, thiazolidinediones (glitazones), meglitinides (glinides), alpha-glucosidase inhibitors and DPP-4 inhibitors. The classes of medications given by injection are incretin mimetics and insulin [17-26]. Mechanisms of these medications have been reported. However, most modern drugs have many side effects and adverse effects, causing some serious medical problems during medication processing. Metformin is one medicine of biguanides which can inhibit the production of glucose molecules in the liver of human and increase insulin sensitivity. However, metformin also causes some main side effects such as gastrointestinal on the initial state, including dyspepsia, nausea and diarrhea. Metformin should be avoided in those with severely compromised renal function, de-compensated heart failure, severe liver disease other serious medical problems. The beneficial effects of thiazolidinediones in diabetes treatment are to improve the sensitivity of insulin, decrease insulin resistance and also decrease cardiovascular risks. However, the most common adverse effects of thiazolidinediones are weight gain and fluid retention, leading to peripheral edema and heart failure. The drugs were avoided to use for patients in similar situations, including heart failure and severe liver problems. Rosiglitazone may have cardiovascular risks, and increase the risk of a heart attack. Pioglitazone has not been available in some countries due to concerns about an increased risk for bladder cancer.

According to IDF's statistics, health expenditure has been increased, increasing from USD 232 billion spent worldwide in 2007, to USD 760 billion in 2019 for adults aged 20-79 years [7]. The economic impact of diabetes has been predicted to continue to increase regularly. The health expenditure can be predicted to reach USD 825 billion by 2030 and USD 845 billion by 2045 . 
Therefore, medication expenditure has become a serious problem for patients with diabetes from developing countries.

Besides modern medication, traditional medicines have been used for a long time and play an important role as alternative medicines [27-30]. According to WHO, a plant-based traditional system of medicine is still the chief support of about $75-80 \%$ of the world population mainly in developing countries having a diversity of plants [31]. Traditional medicines are usually the first choice for primary healthcare of patients in developing countries because of better cultural acceptability, better compatibility with the human body and lesser side effects than modern therapies. Recently, some medicinal plants have been reported to be useful in diabetes worldwide and have been used empirically as antidiabetic and antihyperlipidemic remedies. More than 400 plant species having hypoglycemic activity have been available in the literature [32], however, investigating new antidiabetic drugs from natural plants has still been attractive because they contain phytoconstituents that demonstrate alternative and safe effects on the treatment of diabetes mellitus. Most plants contain bioactive components, such as phenolics, glycosides, alkaloids, terpenoids, flavonoids, carotenoids, etc., that have been improved as having antidiabetic activities [33-36].

\section{Bioactive Compounds from Plants Having Type 2 Antidiabetic Activity}

The hypoglycemic and antidiabetic effects of several plants used as traditional antidiabetic remedies have been proved, and the mechanisms of hypoglycemic activity of these plants have been studied effectively [35-37]. This review focuses on the mechanism of traditional herbal and natural medicines from traditional medicinal plants for diabetes treatment.

\subsection{Bioactive Compounds Act as Insulin}

\subsubsection{Momordica charantia (Bitter Melon)}

Momordica charantia (MC) is one of the most common vegetables in the tropical region, particularly in Vietnam, India, China, East Africa, South-North Asia, and Central and South America [38,39]. It is a member of the Cucurbitaceae family and is known as bitter melon or bitter gourd (Figure 3). Besides using MC as a vegetable, it is supposed to be a herbal medicine, used as folk medicine. Its bioactivities, such as anti-inflammatory activity, anti-oxidant activity, anti-viral activity, anti-cancer activity, anti-bacterial activity, etc. and especially anti-diabetic activity [40].

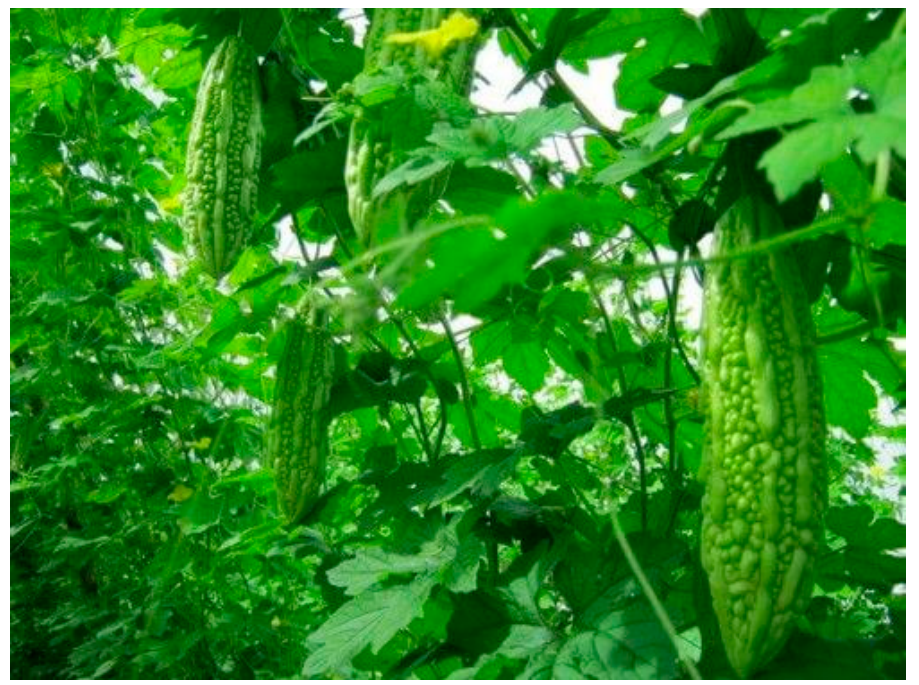

(a)

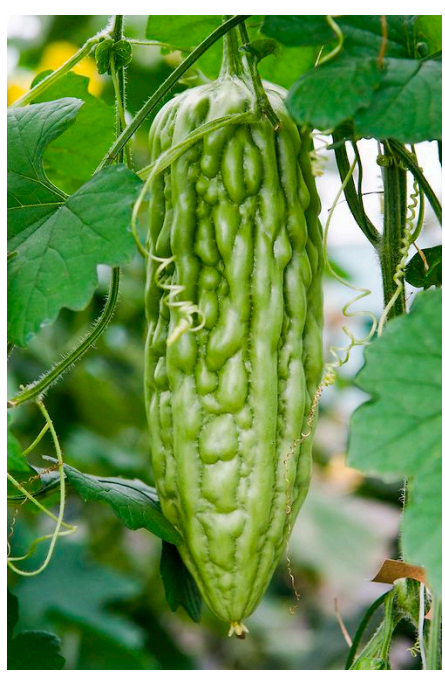

(b)

Figure 3. Pictures show the morphological characteristics of the Momordica charantia (MC): (a) whole plant and (b) unripe fruit. 
Phytochemistry

There were many investigations publishing active components of bitter melon that support type 2 DM treatment. The important phytochemicals of the plants are steroids, momordicosides (A, B, C, D, $\mathrm{E}, \mathrm{G}, \mathrm{F}_{1}, \mathrm{~F}_{2}$, I, K, L), acyl glucosyl sterols, fatty acids, amino acids, alkaloids, phenolic compounds, steroidal saponin, vitamins, carbohydrates, and minerals, etc. [40-48].

Antidiabetic Activity

The fruits, seeds and callus of Momordica charantia contain some insulin-like proteins [49] which are homologous to human insulin, and it produced consistent hypoglycemic effect when tested on rats, gerbils, langurs and human beings [50]. In India and China, MC was believed to be a treatment for diabetes mellitus for thousands of years. Nowadays, scientists have done many types of research focusing on its anti-hyperglycemic abilities. Indeed, many research papers have shown that its bioactivities decrease significantly in blood glucose levels (Figure 4). These investigations on bitter melon also demonstrated that it can enhance the glucose tolerance of normal and diabetic mice and also in humans [47-51]. Many studies proved that bioactive constituents for MC have considerable antidiabetic activities (Table 1).

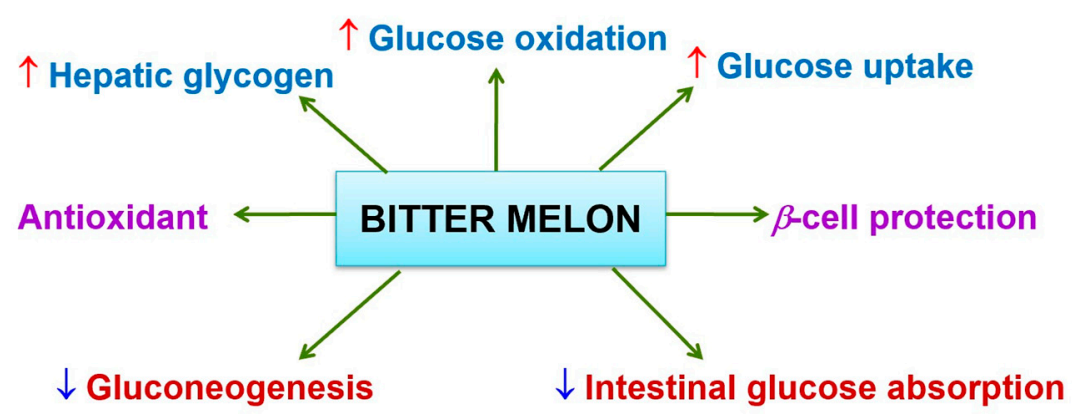

Figure 4. The mechanism in decreasing blood glucose levels of M. charantia.

Table 1. Bioactive compounds and their effects in Momordica charantia.

\begin{tabular}{cc}
\hline Bioactive Compounds & Antidiabetic Effects \\
\hline Polypeptide-p & Act as Insulin-like protein, decrease blood glucose level \\
Momordicosides & Enhance the uptake of glucose \\
Saponins & Stimulate insulin secretion, a lower blood glucose level \\
Conjugated linolenic acid & Release intestinal GLP-1 \\
Momordin & PPAR $\delta$ activation \\
$9 \mathrm{c}, 11 \mathrm{t}, 13 \mathrm{t}$ conjugated linolenic acid & PPAR $\alpha$ activation \\
\hline
\end{tabular}

Akhtar $\mathrm{N}$ et al. reported that Charantin, vicine and polypeptide-p contained in ethanolic extract of MC fresh green whole fruit acted as insulin-like protein, decrease blood glucose level, stimulated insulin secretion, tissue glucose uptake, decreased hepatic gluconeogenesis, stimulated glucose uptake and utilization, inhibited absorption of glucose in the intestine in alloxan-induced diabetic rabbits by $200 \mathrm{mg} / \mathrm{kg}$ b.w dose [52]. In vitro insulin secretion assay, Momordicoside U ( $3 \beta, 7 \beta$-Dihydroxycucurbita-5,23(E)-dien-19-al-25-O- $\beta$-D-glucopyranoside) showed that this compound could enhance the uptake of glucose by evaluation of insulin secretion activity [53]. According to Singh $\mathrm{N}$ et al., alcoholic extract of the whole fruit which was orally administered in adult alloxan-induced diabetic albino rats can recover $\beta$-cells of the islets of Langerhans of the pancreas by $25 \mathrm{mg}, 50 \mathrm{mg}$ and $75 \mathrm{mg}$ doses of the extract [54]. In the acetone extract of this fruit power, the ability of recovery of beta cells of the islets of Langerhans of the pancreas was confirmed when applied to alloxan diabetic albino rats by $25 \mathrm{mg}, 50 \mathrm{mg}$ and $75 \mathrm{mg}$ doses of extract in 8 to 30 days treatment [55]. An investigation on the antidiabetic activities of MC fruit juice in streptozotocin-induced diabetic rats showed that this 
herb possesses the ability to enhance insulin secretion of pancreatic $\beta$-cells, elevate of serum insulin level, improve $\beta$-cell function, decrease insulin resistance, increase glucose utilization in a dose of $10 \mathrm{~mL} / \mathrm{kg} /$ day for 14 days [56]. In cells of the pancreas, Momordica charantia can be able to renew or recover the partially destroyed cells and encourage the secretion of insulin.

Moreover, aqueous ethanolic extract of MC seeds exposed the protection of pancreatic $\beta$-cells in vitro experiment [57]. In the treatment of type 1 diabetes mellitus, MC extract has been proven to possibly definitely improve beta cells in pancreatic islets in streptozotocin-induced type- 1 diabetic rats. Related with type-1 diabetes, polypeptide-p has shown action similar to human insulin in the body and, therefore, may be used as plant-based insulin replacement in patients with type-1 diabetes [58]. Other studies also investigated the inhibition of diabetes-related enzymes, such as alpha-glucosidase and alpha-amylase from MC extracts [59].

\subsubsection{Panax ginseng C.A Meyer}

In Korea, Ginseng is the most famous traditional plant used in folk medicine for a long time (Figure 5). Ginseng belongs to the genus Panax in family Araliaceae [60]. It distributes typically in a cooler climate region that can be found in Eastern Asia such as Korea, Eastern Siberia, Northeast China and North America.

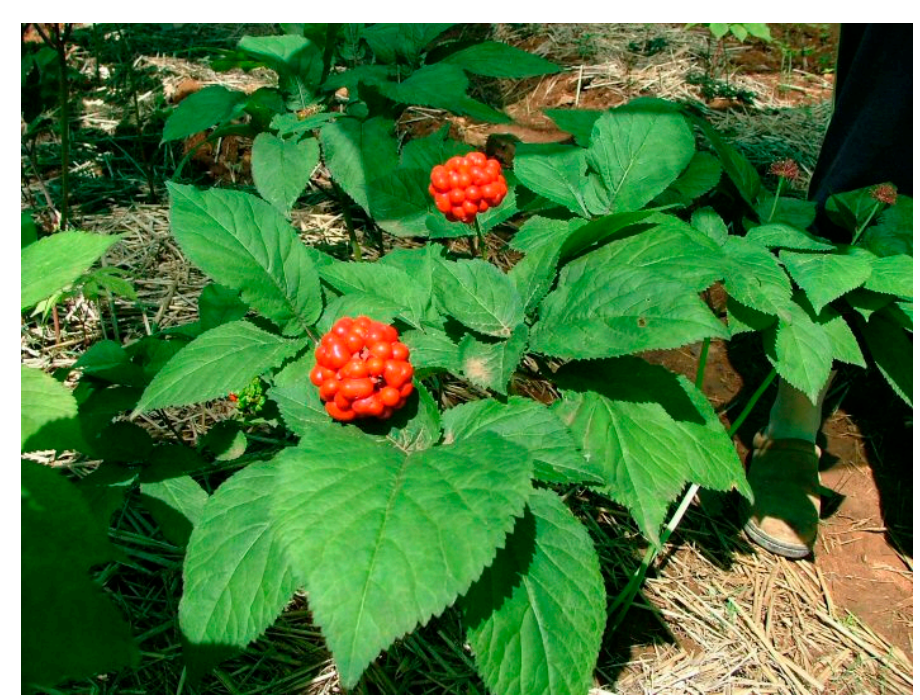

Figure 5. Panax ginseng C.A Meyer.

\section{Phytochemistry}

The root of this plant contains many bioactive compounds, including triterpene glycosides, or saponins, commonly referred to as ginsenosides (Table 2), Panaxans, vanillic acid, salicylates. All parts of the plant also have some active constituent, such as amino acids, alkaloids, phenols, proteins, polypeptides, and vitamins B1 and B2 which have been identified [61-63].

\section{Antidiabetic Activity}

Since diabetes mellitus is characterized by insulin resistance, and $\beta$-cell dysfunction, therapeutic medications should be involved in improving insulin resistance, enhancing glucose uptake, decreasing blood glucose concentration, and protecting/regenerating $\beta$-cell from pancreatic islets. Many researchers have been investigated the anti-diabetic activities on the root of Panax ginseng in vitro and in vivo experiments [62-64]. The most important group of phytochemicals $\mathrm{f}$ Panax ginseng is ginseng-specific saponins called ginsenosides. Among them, Ginsenosied Rb2 was the most effective constituent treated for streptozotocin-induced diabetic rats by decreasing blood glucose level [65]. Moreover, in fermented red ginseng extracts, the content of ginsenoside $\mathrm{Rg} 2, \mathrm{Rg} 3$, and $\mathrm{Rh} 2$ are higher than normal ginseng 
so that those extracts significantly reduced blood glucose levels and increased plasma insulin levels in streptozotocin-induced diabetic rats by orally-administered 100 or $200 \mathrm{mg} / \mathrm{kg}$ extracts dissolved in water, at 10 a.m. daily in three weeks [66]. These mechanisms have been displayed in Figure 6 . In general, saponins, which were isolated from ginseng that has been proven significant antidiabetic activity. The mechanism of these components in antidiabetic treatment is to moderate the enzyme activity $[50,60]$ to influence glucose metabolism and control insulin secretion [67-73].

Table 2. Structure of ginsenosides (ginseng-specific saponins).

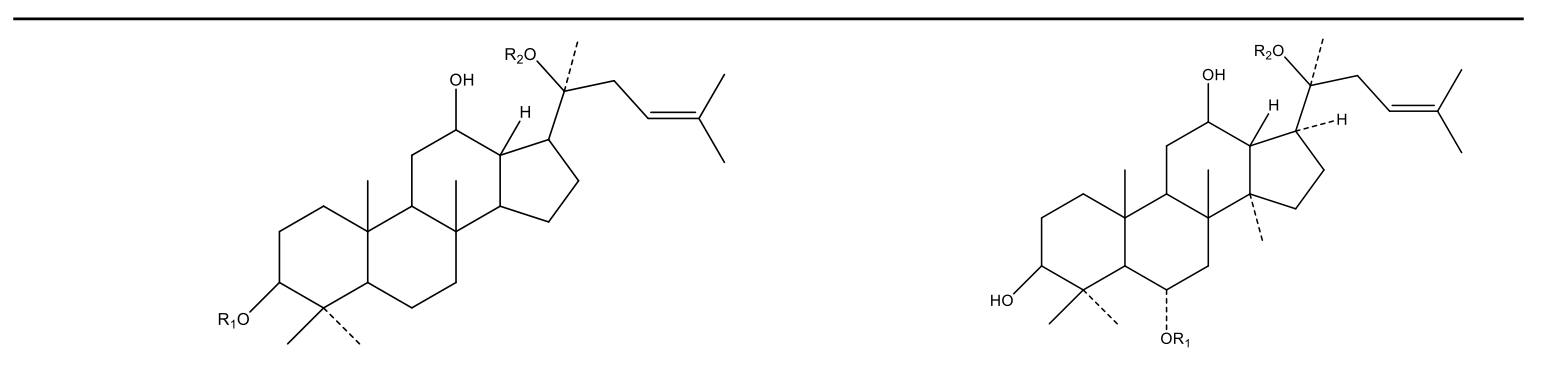

\begin{tabular}{cc}
\hline A. Protopanaxadiol & B. Protopanaxatriol \\
\hline$R_{2}=R a_{1}, R a_{2}, R a_{3}, R b_{1}, R b_{2}, R b_{3}, R c, R d, R g_{2}, R g_{3}, R s_{1}, R s_{2}$, etc. & $R_{2}=R e, R f, R g_{1}, R g_{2}, R h_{1}$, etc. \\
\hline
\end{tabular}

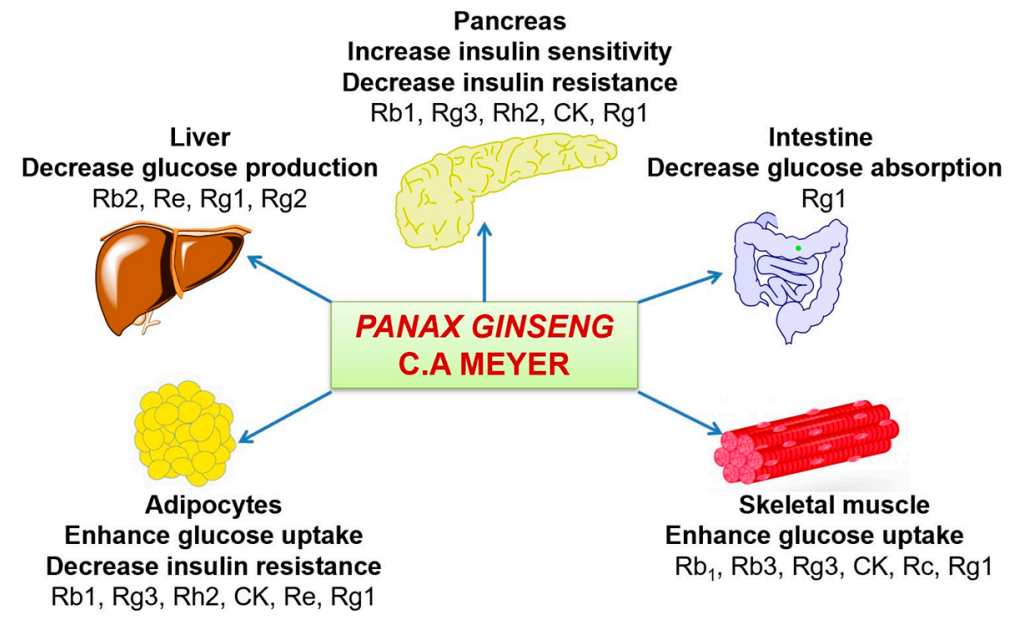

Figure 6. Mechanisms of Panax ginseng saponins on different organs related to diabetes.

\subsection{Bioactive Compounds Increase Insulin Secretion from Beta-Cells of Pancreas}

\subsubsection{Allium cepa (Allium)}

Allium cepa Linn. is a member of the family Liliaceae which is commonly called onion. It is a useful ingredient in cooking in many countries, especially Vietnam, China and Egypt. This plant can survive under harsh conditions, e.g., winter or dryness, so that it can be stored for a long time without any changes in phytonutrients [74].

Phytochemistry

Onion has large numbers of biologically active compounds. These phytoconstituents have been successfully isolated and identified, including phenolics, flavonoids, thiosulfinates, amino acids, essential oils, and vitamins, etc. onion extracts exhibited various bioactivities, such as anti-inflammatory activity, antioxidant activity, and antidiabetic activity, etc. The major biochemical constituents of onion extraction were identified as quercetin, allicin (S-oxodiallyl disulfide), alliin (S-allyl L-cysteine S-oxide), diallyl disulfide (allyl disulfide), S-methyl L-cysteine S-oxide (3-(methyl sulfinyl alanine), propanethial S-oxide (thiopropanal S-oxide) and 3-mercapto-2-methypentan-1-ol [75,76]. 


\section{Antidiabetic Activity}

Hypoglycemic activity of Allium cepa Linn. extracts have been reported [77]. The bulb part contains S-methyl cysteine sulfoxide, S-allyl cysteine sulfoxide has been proven anti-diabetic activity. These compounds can lower blood glucose levels and has a potent antioxidant activity which may account for hypoglycemic potential. S-methylcysteine sulfoxide (Figure 7) exerts antidiabetic action in 3 different ways: (1) stimulate the production of insulin in the body and enhance the secretion of the pancreas; (2) interfere with dietary glucose absorption; and (3) use insulin effectively $[78,79]$.<smiles>CS(=O)CC(N)C(=O)O</smiles>

Figure 7. Structure of S-methyl cysteine sulfoxide.

\subsubsection{Allium sativum (Allium)}

Allium sativum Linn., is commonly herb which has been known as garlic, belongs to the family Allium. It could be found in Asia, Africa and Europe. It is originally indigenous to Asia, is now widely grown in popularity to produce a condiment, especially in Asian cuisine [80].

Their functions prove that garlic is a powerful medicinal plant for treating many diseases for over more than a thousand years. According to numerous scientific research studies, garlic has been discovered as having a wide range of biological functions such as anti-tumor activity, being antibiotics with antimicrobial activity and especially anti-hyperglycemic activity [81].

Phytochemistry

Raw garlic contains many active phytochemicals like alkaloids, flavonoids, cardiac glycosides, terpenes and steroids, resin. It also contains some sulfur compounds, such as alliin, allicin, ajoene, diallyl sulfide, enzymes, B-vitamins, proteins, minerals, saponins, flavonoids, etc., which are not Sulphur-containing compounds [81-84].

\section{Antidiabetic Activity}

Depending on these scientific studies, garlic's biological activity in anti-diabetics has been shown that its mechanism is to control the excretion of insulin from $\beta$-cells, enhance glucose tolerance and glycogen synthesis [85]. For example, these two bioactive compounds, which are extracted from garlic, are allyl propyldisulfide and S-methylcysteine sulfoxide can decrease blood glucose level. In addition, the ethanol extract from garlic was also had antidiabetic activity by restoring delayed insulin response [86,87].

\subsubsection{Aloe vera L. Burm. (Asphodelaceae)}

Aloe vera is the popularly medicinal plant ever known and the most applied medicinal plant especially in the cosmetic industry, and antidiabetic mediation (Figure 8). This traditional medicinal plant belongs to the family Liliaceae. It is original to Africa and Mediterranean countries. It is reported to be distributed widely in the islands of Cyprus, Malta, Sicily, Cape Verde and India [88].

\section{Phytochemistry}

Phytoconstituents in the plant are alkaloids, flavonoids, tannins, phenols, saponins, carbohydrates, vitamins and minerals and several other aromatic compounds [89]. These compounds have been proven for various pharmacological activities, such as antioxidant, antimicrobial, antidiabetic, anti-cancer and so on. That is the result why until now scientists continue to investigate biological activities of this plant to production modern medicine and traditional medicine. 


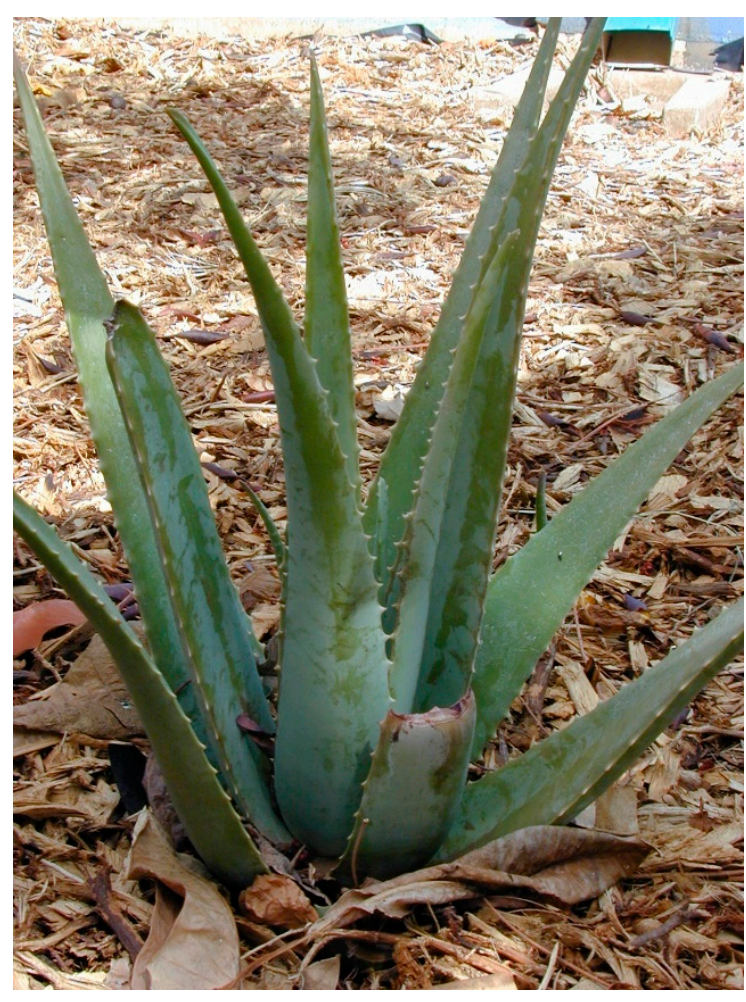

Figure 8. Aloe vera L. Burm.

Antidiabetic Activity

The experiment on diabetic rats treated with Aloe vera water extract orally led to reducing significant blood glucose levels. Statistical analysis of results found that Aloe vera water extract is antidiabetic with fewer side effects [90,91]. Moreover less expensive cost is also a significant benefit of Aloe vera in the production of medicine against diabetes mellitus.

\subsection{Bioactive Compounds Regenerate of Beta-Cells of the Islets of the Pancreas}

\subsubsection{Pterocarpus marsupium (Fabaceae)}

Pterocarpus marsupium (P. marsupium) is a large, high tree that can grow up from 15 to $30 \mathrm{~m}$ tall (Figure 9). It belongs to the Fabaceae family and distributes in India, Nepal, and Sri Lanka, which is widely used in 'Ayurveda' as 'Rasayana' for the management of various metabolic disorders including hyperglycemia [92].

Phytochemistry

Similar to most herbs, P. marsupium is a rich source of phenolic and flavonoid compounds. It has been reported that this plant contains alkaloids, steroids, terpenoids, tannins, amino acids, proteins, etc. The potential antidiabetic constituents in this plant have been identified successfully, including epicatechin. It is also reported to be rich in polyphenolic compounds which have been considered major bioactive compounds, such as marsupsin, pterosupin and pterostilbene and flavonoids pteroside, pteroisoauroside, carsupin and marsupol. These compounds have many biological effects, e.g., anti-inflammatory, anti-bacterial, anti-oxidant activity, especially antidiabetic activity [93-96]. 


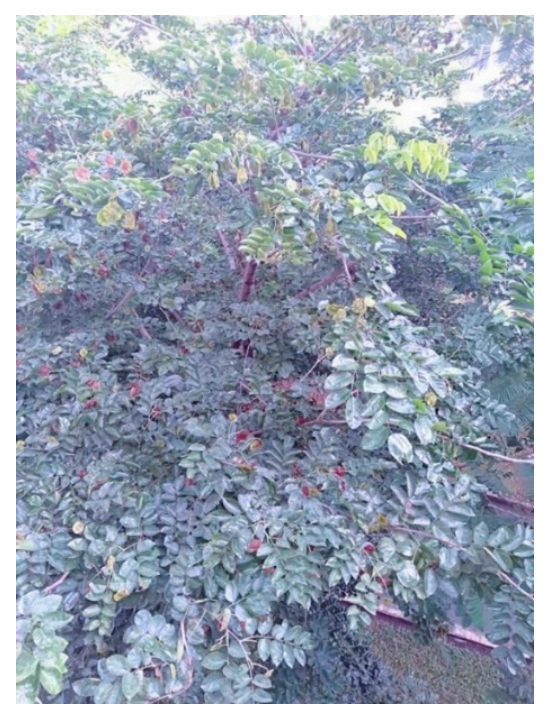

(a)

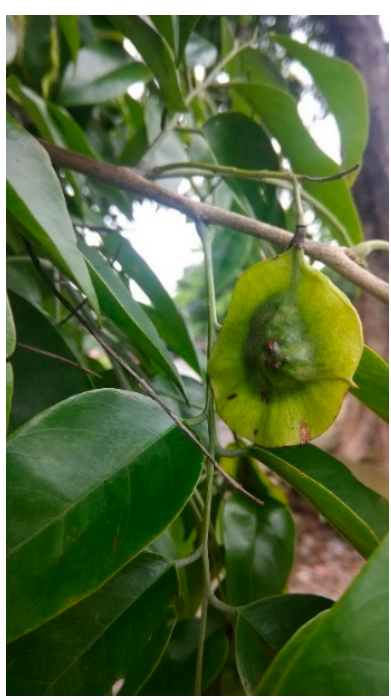

(b)

Figure 9. Pterocarpus marsupium: (a) whole plant and (b) leaves.

Antidiabetic Activity

The extract of $P$. marsupium was orally administered by diabetes patients and gave a strong anti-hyperglycemic effect $[92,94]$. Ethyl acetate's extract of $P$. marsupium was tested for five days on alloxan-induced diabetic rats to conclude the significant anti-diabetes effect. The ethanolic extract of P. marsupium showed the blood sugar lowering effect [95]. It was found to be effective in lowering the glucose level. Epicatechin, isolated from P. marsupium, showed the ability of regeneration of the $\beta$-cells of the pancreas islets [97]. Moreover, the aqueous extract of this plant was reported that it could stimulate the secretion of insulin and enhance the glucose uptake, so that it can be considered as antidiabetic medicine [94].

\subsubsection{Tinospora cordifolia (Menispermaceae)}

Tinospora cordifolia (T. cordifolia) has been commonly known as "Amrita" or "Guduchi", belong to the Menispermaceae family. It has been one of the important drugs of Indian Systems of Medicine for a long time. Guduchi is native to India and mainly distributed in tropical areas such as Myanmar and Sri Lanka [98]. In India, this plant has been reported as the main source of treatments for many diseases such as fever, dyspepsia and urinary diseases in folk medicine [99].

\section{Phytochemistry}

Tinospora cordifolia has been reported to contain numerous constituents belonging to different chemical classes of secondary metabolites such as alkaloids, terpenoids, essential oils, glycosides, steroids, phenolic constituents, aliphatic compounds, and polysaccharides. Leaves of this plant are a rich source of proteins, flavonoids, alkaloids and glycosides [100,101]. These active compounds have been exposed to several biological activities, including antiseptic, anti-inflammatory, anti-cancer, antimicrobial and antidiabetic activities.

\section{Antidiabetic Activity}

T. cordifolia, containing polysaccharide isolated from this plant exposed the $\beta$-cell regenerative properties which could be pointed to develop antidiabetic medicine with few side effects [102]. Oral administration of the extract of T. cordifolia roots for two weeks experimented with induced type 2 diabetic rats resulted in this plant can promote insulin secretion and inhibit glucosgenolysis process and therefore improve the regulation of blood glucose level in the body [103]. In 2011, Patel also studied the hypoglycemic effects of alkaloidal fraction of T. cordifolia extract. This investigation demonstrated 
the antidiabetic activity of $T$. cordifolia due to the promoting of insulin-releasing, improving insulin sensitivity and inhibiting gluconeogenesis process [104].

\subsubsection{Tinospora crispa (Menispermaceae)}

Tinospora crispa (T. crispa) is a precious medicinal climbing plant. As a kind of vines, its body is very rough, light brown, long to 6-7 $\mathrm{m}$ or more (Figure 10). It wildly grows in many South East Asia countries such as Laos, Cambodia, Thailand, and Philippines, etc., particularly common in the Northern areas in Vietnam [105-107].

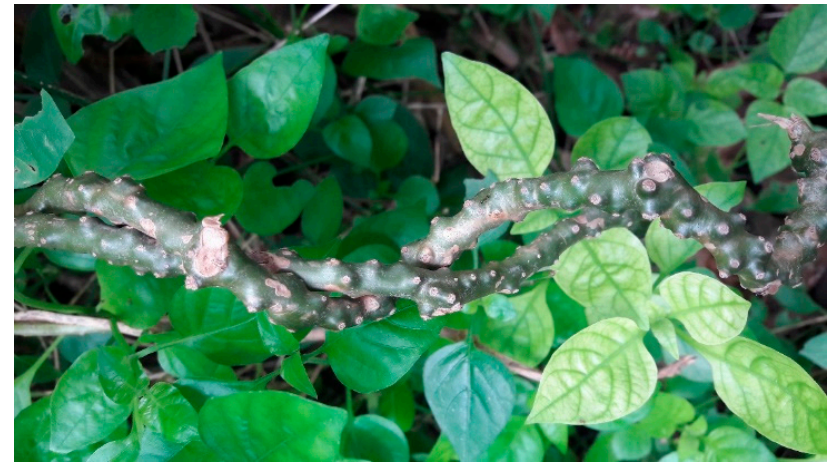

(a)

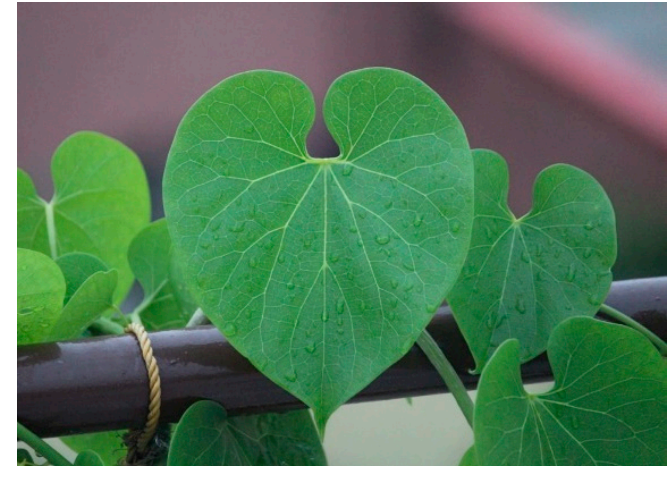

(b)

Figure 10. Tinospora crispa: (a) whole plant and (b) leaves.

Phytochemistry

In many previous investigations, T. crispa is a rich source of secondary metabolites, divided into several groups, including alkaloids, flavonoid, terpenoids, lignans, sterols, etc. [105]. Alkaloidal constituents have been isolated including $N$-formylasimilobine 2-O- $\beta$-D-glucopyranoside, $N$-formylasimilobine 2-O- $\beta$-D-glucopyranosyl-( $1 \rightarrow 2)-\beta$-D-glucopyranoside, (tinoscorside A), $N$-formylanonaine, $\mathrm{N}$-formyldehydroanonaine, $\mathrm{N}$-formylnomuciferine, $\mathrm{N}$-demethyl- $\mathrm{N}$-formyldehydronornuciferine, magnoflorine, etc. [105-108]. Until now, there are several flavones and flavone glycosides which have been isolated and identified from T. crispa extract, such as apeginin, diosmetin, genkwanin, luteolin 4'-methyl ether 7-glucoside, genkwanin 7-glucoside, luteolin 4'-methyl ether $3^{\prime}$-glucoside [109]. Moreover, many researchers reported that this plant also contains a lot of phytochemical bioactive constituents [110].

\section{Antidiabetic Activity}

The investigation of Noor and Ashcroft [106] indicated that the orally administrated extract of T. crispa exhibited a potential antidiabetic effect. The mechanisms of these activities were predicted so that this plant could stimulate insulin secretion through the modulation of $\beta$-cell $\mathrm{Ca}^{2+}$ concentration. In Noipha's experiment, T. crispa extracts improved the glucose transport activity of L6 myotubes by increasing GLUT1 transporter [110]. Thus, it can be further used as an antidiabetic agent for the treatment of type II diabetes [110,111].

\subsubsection{Gymnema sylvestre (Apocynaceae)}

Gymnema sylvestre (G. sylvestre) belonging to the Apocynaceae family, originated from tropical forests of The Southern and Central India and Sri Lanka [112]. In Vietnam, G. sylvestre has been classified as vines and found in many Northern and Central provinces. So far, this plant has been widely used in several countries around the world in treating diabetes. 


\section{Phytochemistry}

The phytoconstituents of G. sylvestre consist of many groups containing bioactive compounds that are listed in the below table (Table 3) [112,113].

Table 3. Classification of phytoconstituents of Gymnema sylvestre.

\begin{tabular}{ll}
\hline \multicolumn{1}{c}{ Phytoconstituents } & \multicolumn{1}{c}{ Classification } \\
\hline Triterpene saponins & $\begin{array}{l}\text { Gymnemic acids-acylated (tiglolyl, methylbutyroyl) derivatives of deacylgymnemic acid } \\
\text { (DAGA) which is a 3-O- } \beta \text {-glucouronide of gymnemagenin }(3 \beta, 16 \beta, 21 \beta, 22 \alpha, 23, \\
\text { 28-hexahydroxy-olean-12-ene) }\end{array}$ \\
\hline Oleanane saponins & Gymnemic acids and gymnemasaponins \\
\hline Dammarene saponins & Gymnemosides A, B, C, D, E, and F \\
\hline Gurmarin & A novel 35-amino-acid peptide with a 4209 molecular weight \\
\hline Triterpenoidsaponins & \\
\hline Gymnemasins A & 3-O [ $\beta$-D-glucopyranosyl (1-3)- $\beta$-D-glucopyranosyl]-22-O-tiglyol gymnemanol \\
\hline Gymnemasins B & 3-O-[ $\beta$-D-glucopyranosyl-(1-3)- $\beta$-D-glucuro-nopyranosyl]-gymnemanol \\
\hline Gymnemasins C & glucuronopyranosyl-22-O-tigloyl-gymnemanol \\
\hline Gymnemasins D & 3-O- $\beta$-D-glucopyranosyl-gymnemanol \\
\hline Gymnemanol & 3, $\beta$-16, $\beta$-22, $\alpha$-23-28-pentahydroxyolean-12-ene \\
\hline Gymmestrogenin & Pentahydroxytriterpene \\
\hline Flavonol glycoside & Kaempferol 3-O- $\beta$-D-glucopyranosyl-(1-4)- $\alpha$-L-rhamnopyranosyl-(1-6)- $\beta$-D-galactopyranoside \\
\hline Sterols & Stigmasterol \\
\hline
\end{tabular}

\section{Antidiabetic Activity}

The major biological active ingredient of G. sylvestre is Gymnemic acids-a group of triterpenoid saponins isolated and identified successfully (Figure 11). Several studies have reported that the main biological activity of this plant is antidiabetic activity [113].

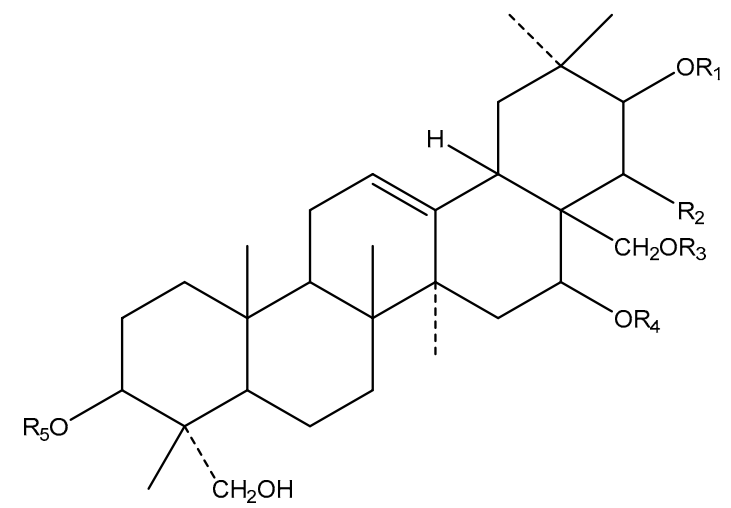

Figure 11. Basic molecular structure of Gymnemic acid.

In the investigation of S. Sathya et al., the aqueous extract of $G$. sylvestre leaf informed hypoglycemic activity in normal and alloxan-induced diabetic rats [114] by reducing glucose concentration. Other research on G. sylvestre extracts suggested that this extract could stimulate the release of insulin in vitro by permeabilizing the $\beta$-cell [115]. Several mechanisms have been proposed to explain the antidiabetic activity of G. sylvestre (Figure 12) [113,116,117]. According to these literature, the action of Gymnemic acids in diabetic treatment was reported to be able to stimulate pancreatic cell production, thereby increasing insulin production, increase insulin sensitivity and insulin activity, help to control and stabilize blood glucose concentration in the body. Gymnemic acids were also reported to be able 
to inhibit the absorption of glucose in the small intestine and inhibit the conversion glycogen in live to glucose molecules in blood [118].

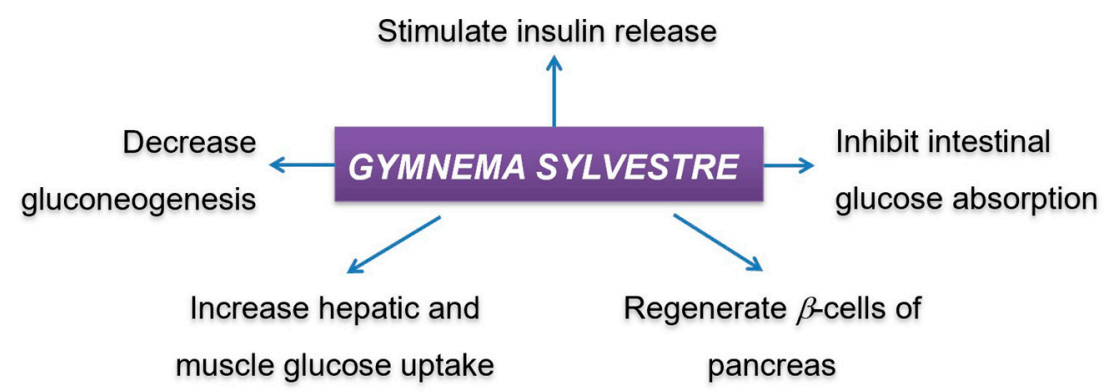

Figure 12. Mechanisms of Gymnema sylvestre in the antidiabetic activity.

\subsection{Bioactive Compounds Reduce the Absorption of Glucose from Gastrointestinal Tract}

\subsubsection{Cyamposis tertragonoloba (Fabaceae)}

Cyamopsis tetragonoloba L. Taub is commonly known as Cluster Bean or Guar, belongs to the Fabaceae family. The plant is a very small drought-resistant herb and widely cultivated in India. This plant was reported to contains a high amount of carbohydrates and fiber [119].

Phytochemistry

There are very few phytochemical studies carried out on this plant. Some phytoconstituents in leaves were reported to contain carbohydrates, proteins, fibers, galactomannans, ascorbic acid and condensed tannins together with, caffic acid, gallic acid, and gentisic acid, $p$-coumaric acid, astragalin, $p$-hydroxycinamyl and coniferyl alcohol. Its flavonoid content includes quercetin, daidizein, kaemferol, and its 3-arabinosides. Moreover, other polyphenolic compositions of the plant were identified, including gallotannins, gallic acid and gallic acid derivatives, myricetin-7-glucoside-3-glycoside, chlorogenic acid, ellegic acid, 2,4,3-trihydroxy benzoic acid, texasin-7-O-glucoside and $p$-coumaryl quinic acid [119].

Antidiabetic Activity

Because of the presence of flavonoids and other phenolic compounds of the plant, Cyamopsis tetragonoloba showed a marginal antihyperglycemic effect on blood glucose level in normal fasted rats, however, the blood glucose-lowering effect was significant in alloxan-induced hyperglycemic rats. Other studies showed that this herb could improve insulin release and decrease the amount of HbA1c $[120,121]$. Gopalsamy Rajiv Gandhi et al. reported that polyphenols identified in C. tetragonoloba beans showed hypoglycemic action and protected $\beta$-cells [122]. Hence this plant can be considered for use in the management of type 2 diabetes mellitus.

\subsubsection{Ocimum sanctum L. (Lamiaceae)}

Ocimum sanctum L. is a small tree, up to $1 \mathrm{~m}$ tall, commonly known as 'Sacred basil' or 'Holy basil' or "Hương Nhu Tía" in Vietnam, is grown as a household plant in many countries for medicinal purposes like Vietnam and India (Figure 13). It belongs to the Lamiaceae family. The whole plant has a pleasant aroma $[123,124]$.

Phytochemistry

The phytochemistry of Ocimum sanctum is identified in all parts of this plant, containing many nutrients and bioactive constituents. However, the quantity of these constituents depends on many natural factors, including growing, harvesting, storage conditions $[125,126]$. 


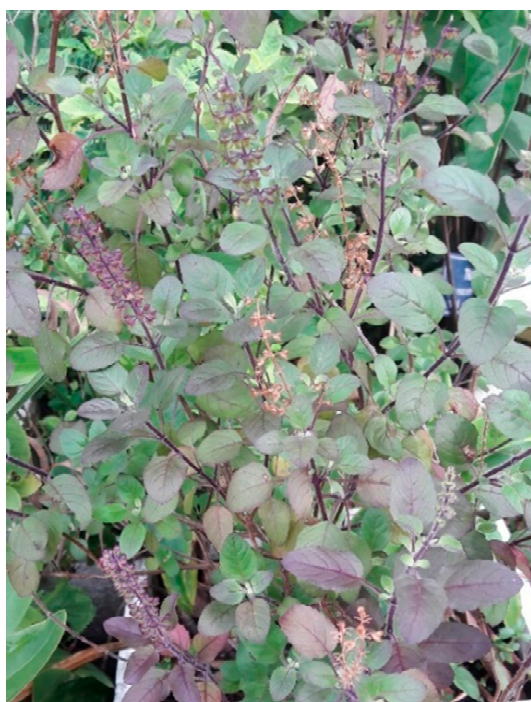

(a)

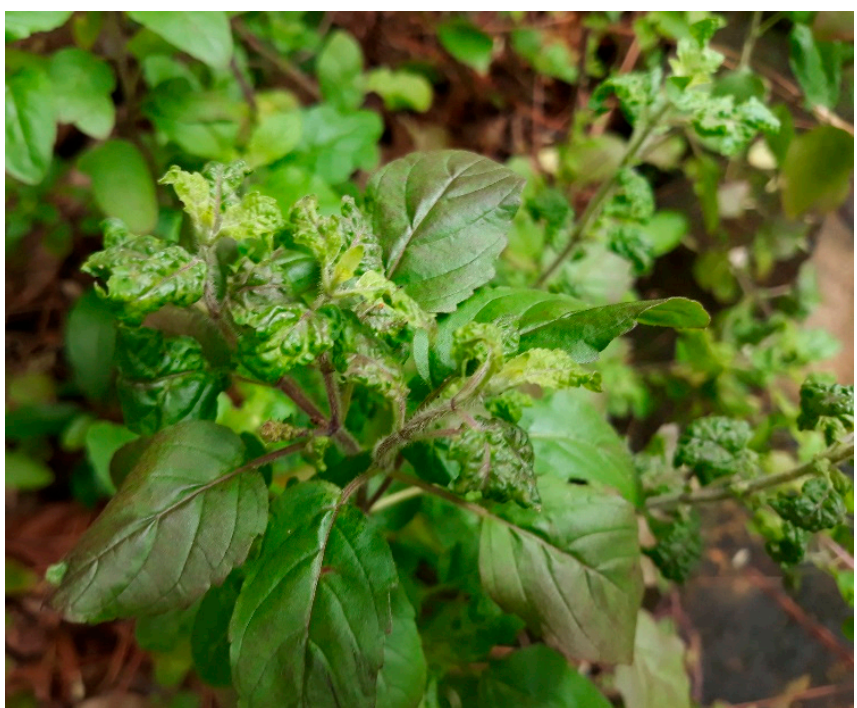

(b)

Figure 13. Ocimum sanctum L.: (a) whole plant and (b) leaves.

In leaf extract of $O$. sanctum, volatile oil was extracted and identified chemical compositions, containing many major components like eugenol, methyleugenol, and $p$-caryophylen. The essential oil of this herb contains various bioactive compounds, such as terpenoids, esters, aliphatic aldehydes and phenolic acids. This herb also consists of a diversity of second metabolites, including phenolics, flavonoids, terpenoids, lignans, steroids, fatty acids and their derivatives. These components have been mainly studied for therapeutic purposes because of their biological and pharmacological effects, including antioxidant, anti-inflammatory, antimicrobial, anticancer and antidiabetic activity [125].

\section{Antidiabetic Activity}

In Hannan's study, there are four fractions of Ocimum sanctum including the ethanol, aqueous, butanol, and ethyl acetate fractions prepared to elucidate the mechanism of antihyperglycemic activity of this plant showed in literature [127]. This result proved that these fractions could stimulate insulin secretion. This study also indicates that the ethanol extract could decrease blood glucose concentration and increase insulin secretion, thereby this plant is a potential herb in diabetic treatment. Moreover, by in vivo experiment, the $O$. sanctum extract was showed to be able to improve oral glucose tolerance, decrease serum glucose, increase glycogen synthesis in the liver [128].

It was reported that leaf power extract lowered plasma glucose level by the presence of many active phytochemicals including eugenol, carvacrol, linalool, caryophylline, $\beta$-sitosterol which have been studied about potent hypoglycemic effects efficiency [76]. The other investigation has reported the antidiabetic and hypoglycemic activities of a triterpenoid (16-hydroxy-4,4,10,13-tetramethyl17-(4-methyl-pentyl)-hexadecahydro-cyclopenta[a]phenanthrene-3-one) isolated from Ocimum sanctum by in vivo investigation [129]. The mechanisms of the antidiabetic and hypoglycemic potential of this compound were elucidated to increase the pancreatic secretion of insulin from $\beta$-cells, and enhance glucose utilization [129]. It was suggested that this triterpenoid should be considered to be developed as a potential antidiabetic medicine. This evidences support that $O$. sanctum has many benefits in the management of diabetes, and this plant should be encouraged to be a potential anti-diabetic activity [130].

\subsection{Bioactive Compounds Have Oxygen Radical Scavenging Activity}

As displayed above, the fruit juice of Momordica charantia herb was determined to be an antioxidant composition because of the radical scavenging effect of the butanol fraction from $M$. charantia extract [131]. As the same result, in 2014, Tsai TH et al. demonstrated antioxidant activity and 
cell-protective activity of $M$. charantia extract because this herb extract could scavenge several free radicals [132]. The antidiabetic action of Momordica charantia has been elucidated through this mechanism. The efficacy of some Indian ayurvedic plant extracts, including Momordica charantia, Eugenia jambolana (Figure 14), Tinospora cordifolia and Mucuna pruriens (Figure 15) was investigated for the prevention of diabetic cataract in vivo. The results showed that Momordica charantia and Eugenia jambolana had better protective activity in the development of diabetic cataract as compared to Tinospora cordifolia and Mucuna pruriens [133].

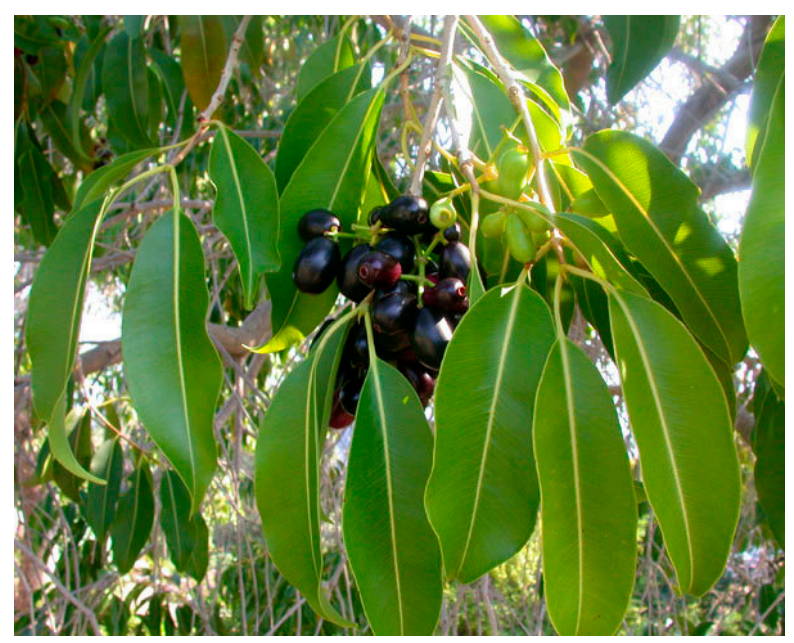

Figure 14. Eugenia jambolana.

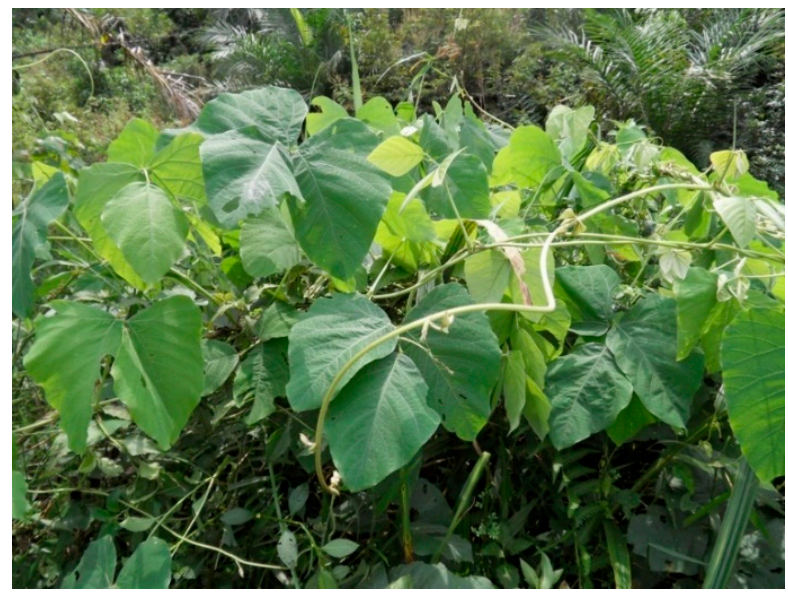

Figure 15. Mucuna pruriens.

\subsection{Bioactive Compounds Inhibit Alpha-Glucosidase and Alpha-Amylase Activities}

Salivary or pancreatic alpha-amylase is an enzyme that catalyzes to hydrolyze $\alpha$-bonds of large, $\alpha$-linked polysaccharides, such as starch in plants and glycogen in animals and humans, to create monosaccharide as glucose. $\alpha$-glucosidase is an enzyme located in the small intestine that hydrolyses terminal non-reducing $(1 \rightarrow 4)$-linked $\alpha$-glucose residues to release a single $\alpha$-glucose molecule. $\alpha$-amylase and $\alpha$-glucosidase are important digestive enzymes affecting blood glucose concentration, especially with patients in diabetes mellitus. The action of these enzymes increases glucose concentration causing hyperlycemic status related to diabetes mellitus. So, the inhibition of the action of these enzymes is one of the most important keys in diabetes treatment [134-138]. Many herbs have been reported so that various phytoconstituents isolated from these plants had potential inhibitory activities of two enzymes, thereby focusing on traditional medicine has been noticed. 


\subsubsection{Costus pictus (Zingiberacea)}

Costus pictus D. Don, commonly known as 'insulin plant' belongs to the Zingiberacea family (Figure 16). It has been famous for antidiabetic activity and is used as a traditional dietary supplement for diabetes treatment in Southern India [139].

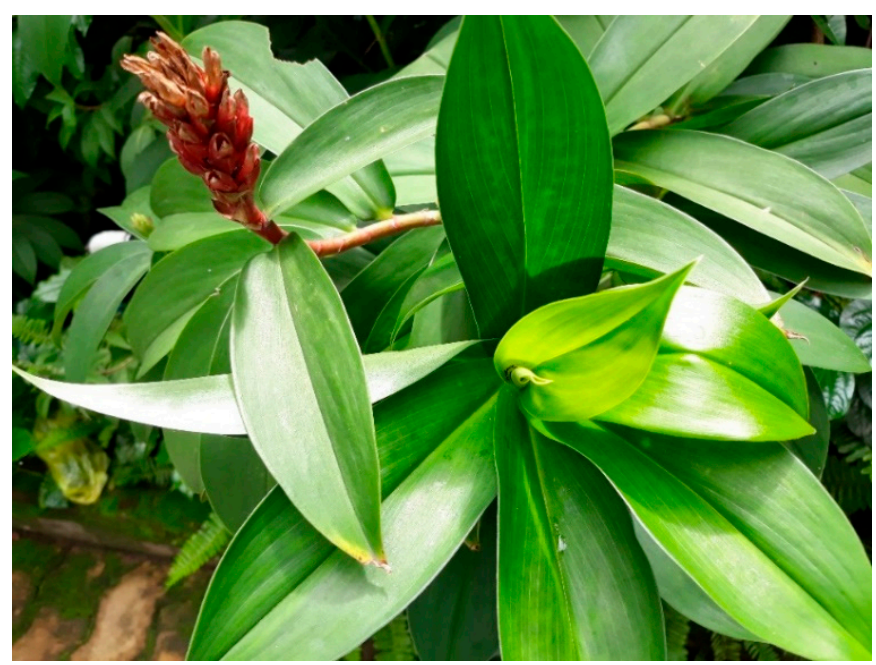

Figure 16. Costus pictus D. Don.

Phytochemistry

The analysis of phytochemicals of $C$. pictus has been reported that most parts of insulin plant including stem, leaves, rhizome and flowers are a diversity of primary and secondary metabolites [139]. Among them, there are many groups of secondary metabolites, including alkaloids, saccharides, terpenoids, glycosides, steroids, tannins, saponins, phenols, flavonoids, etc. [140-143]. Besides the extract of this herb also contains trace elements such as $\mathrm{K}, \mathrm{Ca}, \mathrm{Cr}, \mathrm{Mn}, \mathrm{Cu}$, and $\mathrm{Zn}$ [144].

\section{Antidiabetic Activity}

Until now, various investigations have been carried on an insulin plant to determine anti-diabetic activity [143]. The in vitro study was undertaken to investigate the effects of the C. pictus. The result of that investigation showed that the significant mechanism of antidiabetic activity of Costus pictus is the $\alpha$-amylase and $\alpha$-glucosidase inhibitory activity. In other research, the ethanolic and methanolic extracts of $C$. pictus which have been administrated orally to streptozotocin and alloxan-induced rats have shown a significant reduction in the blood sugar level, and also could increase insulin level [144]. Along with the identification of trace elements like $\mathrm{K}, \mathrm{Ca}, \mathrm{Cr}, \mathrm{Mn}, \mathrm{Cu}$, and $\mathrm{Zn}$ stimulates the antidiabetic property. The other study also reported that antidiabetic property on streptozotocin-induced diabetic rats and in vitro pancreatic islet culture of $C$. pictus. Inhibition of carbohydrates hydrolysing enzymes activity like $\alpha$-amylase and $\alpha$-glucosidase also gave good results [145,146]. In 2009, G. Gireesh et al. carried out an in vivo experiment of $C$. pistus leaf to determine antihyperglycemic activity and insulin secretion in diabetic rats. Their results suggested that insulin plant could lower glucose concentration, increase insulin secretion, and also enhance glucose utilization [147]. Another in vitro study in 2010 showed that Costus pictus extracts could stimulate insulin secretion from $\beta$-cells of islets of Langerhans [148].

\subsubsection{Phaseolus vulgaris (Leguminosae)}

Phaseolus vulgaris L. (P. vulgaris) belongs to the Leguminosae family, commonly known as kidney bean, which is a food item of mass consumption in Asia and Eastern countries [149]. P. vulgaris is an 
annual, herbaceous plant which its main root grows deeply so that this plant has good tolerance with changes of climate. In Vietnam, its fresh beans have been used as a daily vegetable.

Phytochemistry

P. vulgaris has been reported that is an important source of primary and secondary metabolites necessary in a healthy diet of humans. By using the HPLC technique to separate constituents' efficiency, the phytochemicals of P. vulgaris were identified successfully [149-151]. These compounds could be divided into different groups displayed in Table 4.

Table 4. Some major isolated phytoconstituents on P. vulgaris.

\begin{tabular}{ll}
\hline \multicolumn{1}{c}{ Group } & \multicolumn{1}{c}{ Phytochemical Compound } \\
\hline Phenolic acids & $\begin{array}{l}\text { Hydroxybezoic acid and derivatives flavonoids, anthocyanins, flavonols, flavanols, isoflavones, } \\
\text { flavanones, proanthocyanidins, and tannins } \\
\text { Hydroxycinnamic acid and derivatives }\end{array}$ \\
\hline Flavonoids & $\begin{array}{l}\text { Orientin, isoerientin, rutin, myricetin, luteolin, quercetin, kaempferol, myricetin-3-rhamnoside, } \\
\text { hyperoside, isorhamnetin-3-glucoside, isoquercitirn }\end{array}$ \\
\hline Proteins & Vicilin, phytohenmagglutinin, alpha-amylase inhibitor $(\alpha-\mathrm{AI} 1, \alpha$-AI2, and $\alpha$-AIL) \\
\hline
\end{tabular}

Antidiabetic Activity

Various previous studies have shown that seeds of kidney bean have $\alpha$-amylase inhibitors inhibiting $\alpha$-amylase activities in animals and insects, related to control type- 2 diabetes mellitus by inhibition of DPP-IV, and a lectin called phytohaemoagglutinin could adjust the activity of glucagon-like peptides GLP-1 (glucagon-like peptide-1) [152-154]. The common bean P. vulgaris have three isoforms of $\alpha$-amylase inhibitor including $\alpha$-AI1 (known as phaseolamin), $\alpha$-AI2, and $\alpha$-AIL, which has been identified and tested in numerous clinical studies against $\alpha$-amylase action [152,155]. The mechanism of action of these enzyme inhibitors indicated that they could reduce the carbohydrate absorption by inhibiting the activity of $\alpha$-amylases of mammals and insects $[155,156]$. The reduction of the glycemic index may also limit the risks of insulin resistance in diabetes mellitus, thereby control the serious consequences of the disease. Recently, another investigation continues to determine $\alpha$-amylase inhibition of P. vulgaris extract [157]. The present study also indicated that $\alpha$-amylase inhibitor inhibited the $\alpha$-amylase activity significantly, and prolonged treatment with $P$. vulgaris extract could reduce several problems related to diabetes mellitus.

\subsubsection{Euphorbia hirta Linn. (Euphorbiaceae)}

Euphorbia hirta Linn. (E. hirta) is a common herb that belongs to Euphorbia genus of Euphorbiaceae family. Euphorbia hirta L. is found in pan-tropic, partly sub-tropic areas and worldwide including Australia, Western Australia, Northern Australia, Queensland, New south wales, Central America, Africa, Indonesia, Malaysia, Philippines, China and India [158]. In Vietnam, Euphorbia hirta L. is commonly distributed in many provinces of the southern area (Figure 17). Euphorbia hirta L. was used as a traditional medicine in the treatment of diabetes for a long time ago [158-161].

The strong anti-diabetes activity of Euphorbiaceae family in general and E. hirta, in particular, was reviewed in 2006 [84]. Unambiguously, E. hirta can serve as a potential candidate to develop newline anti-diabetes drugs in the future. 


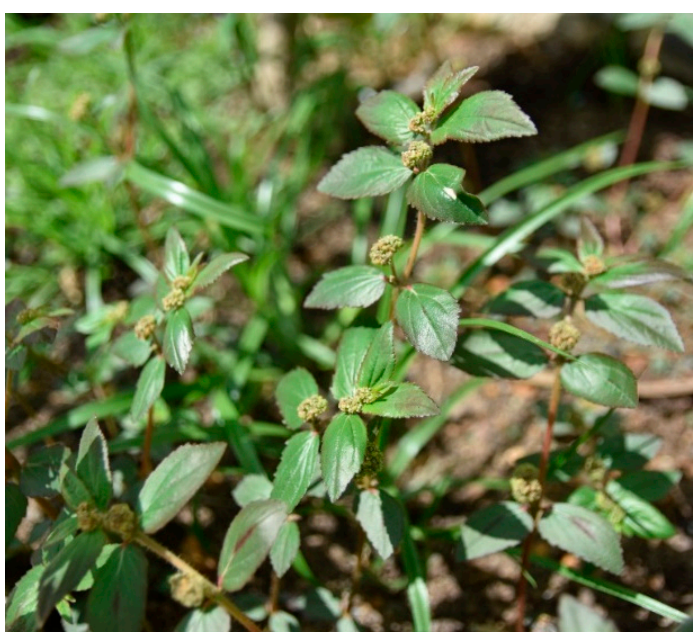

(a)

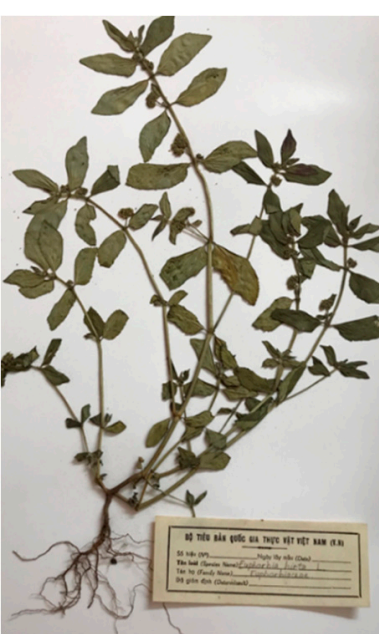

(b)

Figure 17. Euphorbia hirta Linn.: (a) fresh whole plant and (b) plant specimen.

Phytochemistry

Euphorbia hirta contains various bioactive compounds, including flavonoids, terpenoids, phenols, essential oil and other compounds (Table 5). Some flavonoids have been identified in E. hirta including quercetin, quercitrin, quercitol and derivatives. Isolated terpenoids in E. hirta include triterpenoids, $\alpha$-amyrin, $\beta$-amyrin, friedelin, teraxerol, cycloartenol, 24-methylene-cycloartenol, ingenol triacetate $\beta$-sitosterol, campestrol, stigmasterol and so on. Some complex tannins have been also determined in E. hirta extract, such asdimeric hydrolysable dehydro ellagic tannins, euphorbins A, B, C, E, etc. terchebin, the monomeric hydrolysable tannins geraniin, 2,4,6-tri-o-galloyl- $\beta$-D-glucose and 1,2,3,4,6-penta-O-galloyl- $\beta$-D-glucose and the esters 5-O-caffeoyl quinic acid (neo chlorogenic acid), 3,4 -di-o-galloyl quinic acid and benzyl gallate $[159,160]$.

Table 5. Some major isolated phytoconstituents on Euphorbia hirta L.

\begin{tabular}{|c|c|c|}
\hline Group & Compound Name & Structure of Compound \\
\hline Flavonols & Quercetin & он \\
\hline & Kaempferol & \\
\hline Leucoanthocyanidins & Leucocyanidin & \\
\hline
\end{tabular}


Table 5. Cont.

\section{Group}

Flavonoid glycosides

Luteolin-7-O-glucoside

Isoquercitrin

Quercitrin

Myricitrin

Afzelin

\section{Structure of Compound}<smiles>C[C@@H]1O[C@@H](Oc2c(-c3cc(O)c(O)c(O)c3)oc3cc(O)cc(O)c3c2=O)[C@H](O)[C@@H](O)[C@H]1O</smiles><smiles>C[C@@H]1O[C@H](Oc2c(-c3ccc(O)cc3)oc3cc(O)cc(O)c3c2=O)[C@H](O)[C@@H](O)[C@H]1O</smiles><smiles>C[C@H]1[C@@H](CO)O[C@@H](Oc2cc(O)c3c(=O)cc(-c4ccc(O)c(O)c4)oc3c2)[C@H](C)[C@@H]1O</smiles><smiles>C[C@@H]1O[C@H](Oc2c(-c3ccc(O)cc3)oc3cc(O)cc(O)c3c2=O)[C@H](O)[C@@H](O)[C@H]1O</smiles> 
Table 5. Cont.

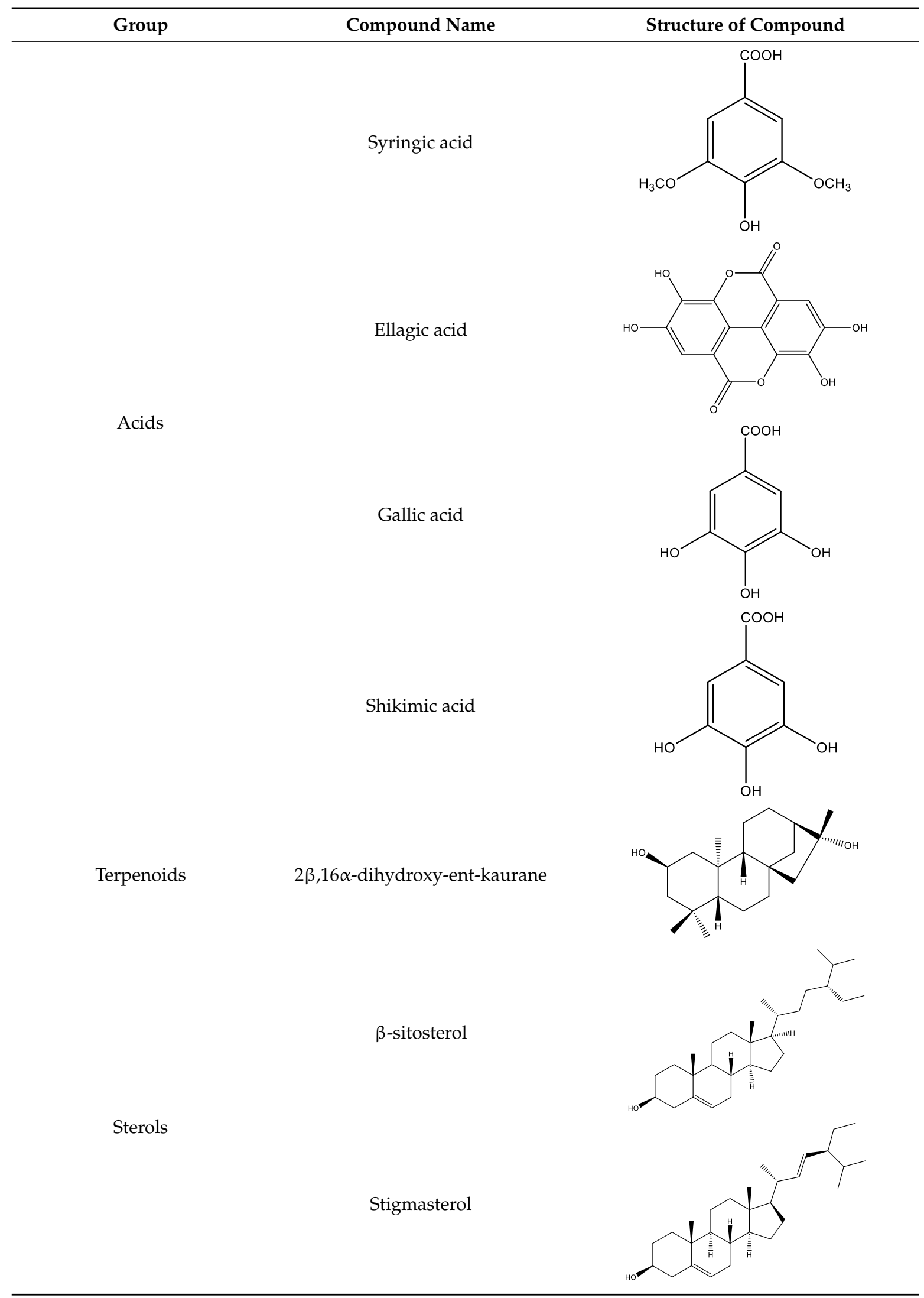




\section{Anti-Diabetic Activity}

The ethanolic extract of Euphorbia hirta was reported to be able to decrease blood glucose level (hypoglycemic effect) on alloxan-induced diabetic rats. From other in vitro experiments, ethanol extract and ethyl acetate fractions inhibit $\alpha$-glucosidase activity. In vivo tests also had the same result. [158-160]. The presence of various bioactive compounds, especially in chloroform and ethyl acetate extracts demonstrated the ability in the treatment of diabetes by inhibition of enzymes involving in the metabolism of saccharides such as $\alpha$-amylase [161]. Polyphenolic compounds have popularly reported inhibitory activity against $\alpha$-amylase in both in vitro and in vivo experiments. Phenolics and flavonoids found in E. hirta such as quercetin, quercitrin, and rutin have been proved to be effective inhibitors of mammalian $\alpha$-amylase. Although the $\alpha$-amylase inhibitory activity of E. hirta powder is not strong enough as acarbose-a standard drug in diabetes treatment-it also proved that E. hirta had mild $\alpha$-amylase inhibition. Until 2010 Sunil Kumar, Rashmi and D. Kumar presented the evaluation of the antidiabetic activity of Euphorbia hirta Linn. in streptozotocin-induced diabetic mice [160]. In 2014, the ethanolic extract of Euphorbia hirta was reported that it can decrease blood glucose level (hypoglycemic effect) on alloxan-induced diabetic rats. From other in vitro experiments, ethanol extract and ethyl acetate fractions inhibited $\alpha$-glucosidase activity. In vivo tests also had the same result [158]. In 2015 Manjur Ali Sheliya and his partners studied the inhibition of $\alpha$-glucosidase by new prenylated flavonoids from E. hirta [162] isolated from ethyl acetate fraction of methanolic extract. By using medium pressure liquid chromatography technique, they successfully isolated four active compounds, including quercetrin (1), dimethoxy quercetrin (2), hirtacoumaroflavonoside (7-O-( $p$-coumaroyl)-5,7,4'-trihydroxy-6-(3,3-dimethylallyl)-flavonol-3-O- $\beta$-Dglucopyranosyl-(2"-1"')-O- $\alpha$-L-rhamnopyranoside) (3) and hirtaflavonoside-B (5,7,3', $4^{\prime}$-trihydroxy-6(3,3-dimethylallyl)-8-(iso-butenyl)-flavonol-3-C- $\beta$-D-glucopyranoside) (4) respectively. The $\alpha$-glucosidase inhibitory activity of isolated compounds was evaluated and compared with standard drug acarbose. The result showed that those flavonoids increased $\alpha$-glucosidase inhibition. That study provides credence to the ethnomedicinal use of E. hirta in the management of diabetes in folk medicine. In 2016 Manjur Ali Sheliya and his group continued to investigate in vitro $\alpha$-glucosidase and $\alpha$-amylase inhibition by aqueous, hydroalcoholic, and alcoholic extract of $E$. hirta [163]. According to their study, the result clearly indicated that the metholic extract of $E$. hirta had strong inhibitory activity against $\alpha$-glucosidase and quietly mild inhibitory activity against $\alpha$-amylase, two proteins involved in diabetes mellitus directly. E. hirta extract can be used for control of postprandial hyperglycemia with lesser side effects, and provide good material for further studies on treatment type 2 diabetes mellitus.

An in silico study, In 2013 Dr. Ly Le and her group investigated antidiabetic activities of bioactive compounds in Euphorbia hirta Linn using molecular docking and pharmacophore [164]. This study demonstrated the effect of bioactive compounds isolated in E. hirta on some proteins relating to diabetes type 2 , including $\alpha$-glucosidase and $\alpha$-amylase by evaluating whether a relationship exists between various bioactive compounds in E. hirta and targeted protein relating diabetes type 2 in human. By calculating the binding energy and pharmacophore modeling, eight promising compounds in E. hirta were obtained, including cyanidi 3,5-O-diglucose, myricitrin, pelargonium-3,5-diglucose, quercitrin, rutin, $\alpha$-amyrine, $\beta$-amyrine, and taraxerol. The results of that investigation showed that those bioactive compounds have the potential in developing medication for type 2 diabetes mellitus. However, the combination of using the molecular dynamic technique is required to determine more accurate binding affinities and the stability of ligand-proteins' interactions. Thus, the research results in silico and in vitro studies have shown that this plant has the ability to inhibit two enzymes.

\subsection{Bioactive Compounds Increase Glucose Utilization}

Some medicinal plants such as Cyamospsis tetragonolobus (Gowar plant) [165], Grewia asiatica (phalsa) [166] and Zingiber officinale Rosc (ginger) [166], were reported their hypoglycemic activity by moderating glucose utilization in the body [167]. This part only displays about Zingiber officinale Rosc. because this herb has been popular and useful in Vietnam. 


\subsubsection{Zingiber officinale Rosc (Ginger)}

It is a traditionally flowering spicy plant in the family Zingiberaceae which was originally native to southern China, and has been grown in many countries in the tropical and subtropical areas, from East Asia to Southeast Asia and South Asia. All parts of this plant, including rhizome, ginger root are widely used as essential food spices or traditional medicine (Figure 18) [168,169].

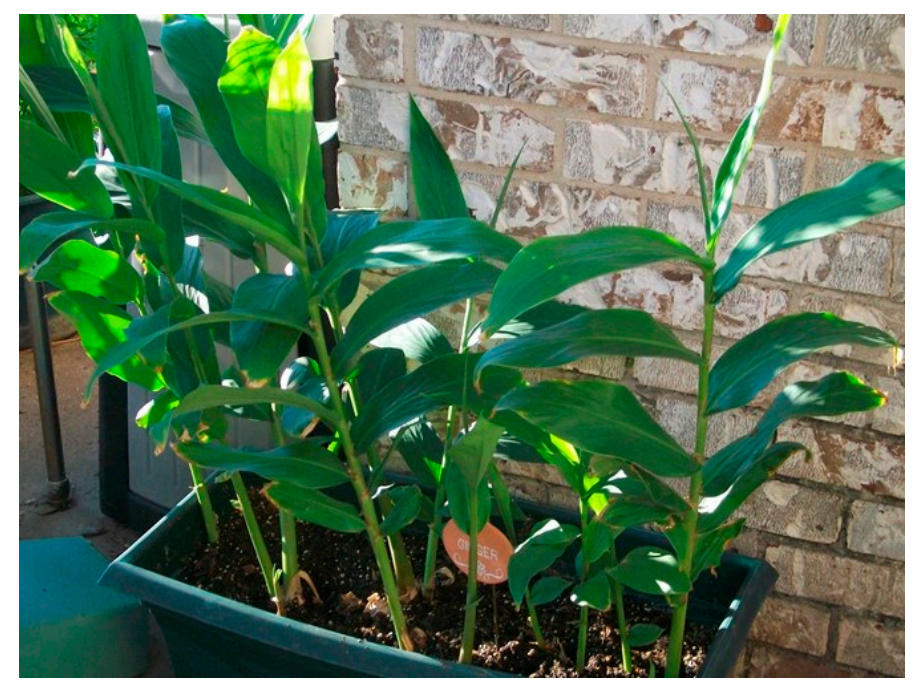

Figure 18. Zingiber officinale Rosc.

Phytochemistry

The phytochemicals of ginger are quite different depending on the origin and the fresh or dry state of parts of this herb. The phytochemicals of rhizome ginger contain strong free-radical reducing efficacy. They include volatile oils, phenolic compounds and others. Among them, volatile oils, also known as ginger essential oils, are a mixture of terpenoid compounds, including sesquiterpene hydrocarbons, monoterpene hydrocarbons, carbonyl compounds, alcoholsand esters. Especially, the phenolics in ginger are the most important components. The phenolic constituents were divided into two groups: gingerol-, gingeron- and shogaol-related group and diarylheptanoids. Gingerol which is the spicy component of this plant contains a diversity of various bioactive substances. Besides, this plant also contains a variety of amino acids, including glutamate, aspartic acid, serine, glycine, threonine, alanine, etc. Moreover, ginger also contains polysaccharides and organic acids, such as oxalic acid, tartaric acid, etc. [168-170].

\section{Antidiabetic Activity}

Sharma and Shukla reported that ginger juice can lower blood glucose concentration in normal fasting animals and in alloxan diabetic animals [171]. The mechanism of lowering the glucose effect was explained because it can increase the viscosity of gastrointestinal contents, slow gastric emptying and also acts as a barrier to diffusion. Other studies also demonstrated that folk medicinal plant ginger can control tissue glycogen content in diabetic rats by improving the peripheral utilization of glucose and repairing the impaired liver [172].

Moreover, the rhizome of Zingiber officinale Rosc also proved that its bioactive components can enhance glucose uptake in cultured L6 myotubes [173]. That investigation suggested that the phenolic gingerol constituents were the major active compounds enhancing glucose uptake. Other investigations showed that the solution of the fresh ginger sample exhibited inhibition against alpha-amylase and alpha-glucosidase activities and inhibit angiotensin-converting enzyme [174,175].

Furthermore, powder of ginger can decrease the level of glucose and activate inflammatory activity which can lead to the development of insulin resistance [176]. 


\section{Conclusions}

Diabetes mellitus has been considered to be a major cause affecting the economy of patients, their families and society. Furthermore, uncontrolled diabetes leads to serious chronic complications such as blindness, kidney failure, and heart failure. In order to decrease this problem, researches on new antidiabetic agents are concerned. Because of the adverse effects of modern therapies, many traditional medicines have been noticed. Moreover, herbal extracts nowadays can be used with standard drugs for combinatorial therapies. Each herb has its own active ingredients that can lower blood sugar levels as well as control the complications of diabetes. Future research will focus on isolation, purification, and identification of bioactive substances in plants. This review is looking forward to providing the necessary information in the management of diabetes. In our review, we have introduced a complete list of anti-diabetic plants taken from the Vietherb database [177]. Isolation and identification of bioactive phytochemicals from these plants play an important role in improving insights into anti-diabetic functional food [161] and drug development [178].

Author Contributions: Conceptualization, N.T. and L.L.; methodology, N.T. and L.L.; software, L.L. and B.P.; validation, N.T. and L.L.; formal analysis, L.L., and N.T.; investigation, N.T., and L.L.; resources, N.T.; data curation, N.T.; writing-original draft preparation, L.L. and N.T.; writing—review and editing, N.T. and L.L.; visualization, L.L. and N.T.; supervision, L.L. and N.T.; project administration, N.T. and L.L.; funding acquisition, B.P. All authors have read and agreed to the published version of the manuscript.

Funding: This work was supported by the Asian Office of Aerospace Research and Development (AOARD) under grand number Grant No. FA2386-19-1-4032

Conflicts of Interest: The authors declare no conflict of interest.

\section{References}

1. World Health Organization. Definition, Diagnosis and Classification of Diabetes Mellitus and Its Complications; Department of Noncommunicable Disease Surveillance: Geneva, Switzerland, 1999.

2. American Diabetes Association. 2. Classification and diagnosis of diabetes: Standards of Medical Care in Diabetes-2019. Diabetes Care 2019, 42 (Suppl. 1), S13-S28. [CrossRef]

3. Heise, T.; Nosek, L.; Rønn, B.B.; Endahl, L.; Heinemann, L.; Kapitza, C.; Draeger, E. Lower within-subject variability of insulin detemir in comparison to $\mathrm{NPH}$ insulin and insulin glargine in people with type 1 diabetes. Diabetes 2004, 53, 1614-1620. [CrossRef] [PubMed]

4. McIntyre, H.D.; Catalano, P.; Zhang, C.; Desoye, G.; Mathiesen, E.R.; Damm, P. Gestational diabetes mellitus. Nat. Rev. Dis. Primers 2019, 5, 47. [CrossRef] [PubMed]

5. Faselis, C.; Katsimardou, A.; Imprialos, K.; Deligkaris, P.; Kallistratios, M.; Dimitriadis, K. Microvascular Complications of Type 2 Diabetes Mellitus. Curr. Vasc. Pharmacol. 2020, 18, 117-124. [CrossRef] [PubMed]

6. Mayfield, J. Diagnosis and classification of diabetes mellitus: New criteria. Am. Fam. Physician. 1998, 58, 1355-1362, 1369-1370. [PubMed]

7. International Diabetes Federation. IDF Diabetes Atlas, 9th ed.; International Diabetes Federation: Brussels, Belgium, 2019.

8. Medagama, A.B.; Bandara, R. The use of complementary and alternative medicines (CAMs) in the treatment of diabetes mellitus: Is continued use safe and effective? Nutr. J. 2014, 13, 102. [CrossRef]

9. Alqathama, A.; Alluhiabi, G.; Baghdadi, H.; Aljahani, L.; Khan, O.; Jabal, S.; Makkawi, S.; Alhomoud, F. Herbal medicine from the perspective of type II diabetic patients and physicians: What is the relationship? BMC Complement. Med. Ther. 2020, 20, 65. [CrossRef]

10. Kesavadev, J.; Saboo, B.; Sadikot, S.; Das, A.K.; Joshi, S.; Chawla, R.; Thacker, H.; Shankar, A.; Ramachandran, L.; Kalra, S. Unproven therapies for diabetes and their implications. Adv. Ther. 2017, 34, 60-77. [CrossRef]

11. Knight, K. A systematic review of diabetes disease management programs. Am. J. Manag. Care 2005, 11, 242-250.

12. Colberg, S.R.; Sigal, R.J.; Yardley, J.E.; Riddell, M.C.; Dunstan, D.W.; Dempsey, P.C.; Horton, E.S.; Castorino, K.; Tate, D.F. Physical activity/Exercise and Diabetes: A Position Statement of the American Diabetes Association. Diabetes Care 2016, 39, 2065-2079. [CrossRef] 
13. Khan, M.U. Lifestyle Modification in the Prevention of Type II Diabetes Mellitus. Oman Med. J. 2012, 27, 170-171. [CrossRef] [PubMed]

14. Bhoyar, P.K.; Tripathi, A.K.; Baheti, J.R.; Biyani, D. Herbal Antidiabetics: A Review. Int. J. Res. Pharm. Sci. 2011, 2, 30-37.

15. Wang, Z.; Wang, J.; Chan, P. Treating Type 2 Diabetes Mellitus with Traditional Chinese and Indian Medicinal Herbs. Evid. Based Complement. Altern. Med. 2013, 2013, 343594. [CrossRef] [PubMed]

16. Thulé, P.M. Mechanisms of current therapies for diabetes mellitus type 2. Adv. Physiol. Educ. 2012, 36, $275-283$. [CrossRef] [PubMed]

17. DeFronzo, R.A. Pharmacologic therapy for type 2 diabetes mellitus. Ann. Intern. Med. 1999, 131, $281-303$. [CrossRef]

18. Goldberg, R.B.; Kendall, D.M.; Deeg, M.A.; Buse, J.B.; Zagar, A.J.; Pinaire, J.A.; Tan, M.H.; Khan, M.A.; Perez, A.T.; Jacober, S.J.; et al. A comparison of lipid and glycemic effects of pioglitazone and rosiglitazone in patients with type 2 diabetes and dyslipidemia. Diabetes Care 2005, 28, 1547-1554. [CrossRef]

19. Home, P.D.; Phil, D.; Pocock, S.J.; Beck-Nielsen, H.; Gomis, R.; Hanefeld, M.; Jones, N.P.; Komajdam, M.; McMurray, J.J.V. Rosiglitazone evaluated for cardiovascular outcomes-an interim analysis. N. Engl. J. Med. 2007, 357, 28-38. [CrossRef]

20. Singh, S.; Loke, Y.K.; Furberg, C.D. Thiazolidinediones and heart failure: A teleo-analysis. Diabetes Care 2007, 30, 2148-2153. [CrossRef]

21. Siconolfi-Baez, L.; Banerji, M.A.; Lebovitz, H.E. Characterization and significance of sulfonylurea receptors. Diabetes Care 1990, 13, 2-8. [CrossRef]

22. Simonson, D.C.; Ferrannini, E.; Bevilacqua, S.; Smith, D.; Barrett, E.; Carlson, R.; DeFronzo, R. Mechanism of improvement in glucose metabolism after chronic glyburide therapy. Diabetes 1984, 33, 838-845. [CrossRef]

23. Lebovitz, H.E. Thiazolidinediones: The Forgotten Diabetes Medications. Curr. Diabetes Rep. 2019, $19,151$. [CrossRef] [PubMed]

24. Perfetti, R.; Ahmad, A. Novel sulfonylurea and non-sulfonylurea drugs to promote the secretion of insulin. Trends Endocrinol. Metab. 2000, 11, 218-223. [CrossRef]

25. Hanefeld, M.; Bouter, K.P.; Dickinson, S.; Guitard, C. Rapid and short-acting mealtime insulin secretion with nateglinide controls both prandial and mean glycemia. Diabetes Care 2000, 23, 202-207. [CrossRef] [PubMed]

26. Jovanovic, L.; Dailey, G., III; Huang, W.C.; Strange, P.; Goldstein, B.J. Repaglinide in type 2 diabetes: A 24-week, fixed-dose efficacy and safety study. J. Clin. Pharmacol. 2000, 40, 49-57. [CrossRef]

27. Yakubu, O.E.; Imo, C.; Shaibu, C.; Akighir, J.; Ameh, D.S. Effects of Wthanolic Leaf and Sterm-bark Extracts of Adansonia digitate in Alloxan-induced Diabetic Wistar Rats. J. Pharmacol. Toxicol. 2020, 15, 1-7. [CrossRef]

28. Chan, C.H.; Ngoh, G.C.; Yusoff, R. A brief review on anti-diabetic plants: Global distribution, active ingredients, extraction techniques and acting mechanisms. Pharmacogn. Rev. 2012, 6, 22-28. [CrossRef]

29. Harris, M.I. Health care and health status and outcomes for patients with type 2 diabetes. Diabetes Care 2000, 23, 754-758. [CrossRef]

30. Preethi, P.J. Herbal medicine for diabetes mellitus: A Review. Int. J. Phytopharm. 2013, 3, 1-22. [CrossRef]

31. Evans, M. A Guide to Herbal Remedies; Orient Paperbacks: Delhi, India, 1994; ISBN-10: 8122201628.

32. Patel, D.K.; Prasad, S.K.; Kumar, R.; Hemalatha, S. An overview on antidiabetic medicinal plants having insulin mimetic property. Asian Pac. J. Trop. Biomed. 2012, 2, 320-330. [CrossRef]

33. Malviya, N. Antidiabetic Potential Of Medicinal Plants. Acta Pol. Pharm. 2010, 67, 113-118.

34. Grover, J.K.; Yadav, S.; Vats, V. Medicinal plants of India with anti-diabetic potential. J. Ethnopharmacol. 2002, 81, 81-100. [CrossRef]

35. Aggarwal, N.; Aggarwal, S. A Review of Recent Investigations on Medicinal Herbs Possessing AntiDiabetic Properties. J. Nutr. Disord. Ther. 2011. [CrossRef]

36. Kayarohanam, S.; Kavimani, S. Current Trends of Plants Having Antidiabetic Activity: A Review. J. Bioanal. Biomed. 2015, 7, 55-65. [CrossRef]

37. Sidhu, M.C.; Sharma, T. Medicinal Plants From Twelve Families Having Antidiabetic Activity: A Review. Am. J. PharmTech Res. 2013, 3, 36-52.

38. Li, W.L.; Zheng, H.C.; Bukuru, J.; De Kimpe, N. Natural medicines used in the traditional Chinese medical system for therapy of diabetes mellitus. J. Ethnopharmacol. 2004, 92, 1-21. [CrossRef] [PubMed] 
39. Rathi, S.S.; Grover, J.K.; Vats, V. The effect of Momordica charantia and Mucuna pruriens in experimental diabetes and their effect on key metabolic enzymes involved in carbohydrate metabolism. Phytother. Res. 2002, 16, 236-243. [CrossRef] [PubMed]

40. Saeed, F.; Afzaal, M.; Niaz, B.; Arshad, M.U.; Tufail, T.; Hussain, M.B.; Javed, A. Bitter melon (Momordica charantia): A natural healthy vegetable. Int. J. Food Prop. 2018, 21, 1270-1290. [CrossRef]

41. Dandawate, P.R.; Subramaniam, D.; Padhye, S.B.; Anant, S. Bitter Melon: A Panacea for Inflammation and Cancer. Chin. J. Nat. Med. 2016, 14, 81-100. [CrossRef]

42. Ibrahim, T.A.; El-Hefnawy, H.M.; El-Hela, A.A. Antioxidant Potential and Phenolic Acid Content of Certain Cucurbitaceous Plants Cultivated in Egypt. Nat. Prod. Res. 2010, 24, 1537-1545. [CrossRef]

43. Tan, S.P.; Stathopoulos, C.; Parks, S.; Roach, P. An Optimised Aqueous Extract of Phenolic Compounds from Bitter Melon with High Antioxidant Capacity. Antioxidants 2014, 3, 814-829. [CrossRef]

44. Popovich, D.G.; Li, L.; Zhang, W. Bitter Melon (Momordica Charantia) Triterpenoid Extract Reduces Preadipocyte Viability, Lipid Accumulation and Adiponectin Expression in 3T3-L1 Cells. Food Chem. Toxicol. 2010, 48, 1619-1626. [CrossRef] [PubMed]

45. Chuang, C.Y.; Hsu, C.; Chao, C.Y.; Wein, Y.S.; Kuo, Y.H.; Huang, C.J. Fractionation and identification of 9c, 11t, 13t-conjugated linolenic acid as an activator of PPARalpha in bitter gourd (Momordica charantia L.). J Biomed Sci. 2006, 13, 763-772. [CrossRef] [PubMed]

46. Ahmad, Z.; Zamhuri, K.F.; Yaacob, A.; Siong, C.H.; Selvarajah, M.; Nazrul, I.A.; Hakim, M. In Vitro Antidiabetic Activities and Chemical Analysis of Polypeptide-K and Oil Isolated from Seeds of Momordica Charantia (Bitter Gourd). Molecules 2012, 17, 9631-9640. [CrossRef] [PubMed]

47. Keller, A.C.; Ma, J.; Kavalier, A.; He, K.; Brillantes, A.M.; Kennelly, E.J. Saponins from the traditional medicinal plant Momordica charantia stimulate insulin secretion in vitro. Phytomedicine 2011, 19, 32-37. [CrossRef] [PubMed]

48. Sasa, M.; Inoue, I.; Shinoda, Y.; Takahashi, S.; Seo, M.; Komoda, T.; Awata, T.; Katayama, S. Activating effect of momordin, extract of bitter melon (Momordica Charantia L.), on the promoter of human PPAR delta. J. Atheroscler. Thromb. 2009, 16, 888-892. [CrossRef]

49. Khanna, P.; Jain, S.C.; Panagariya, A.; Dixit, V.P. Hypoglycemic activity of polypeptide-p from a plant source. J. Nat. Prod. 1981, 44, 648-655. [CrossRef]

50. Dans, A.M.; Villarruz, M.V.; Jimeno, C.A.; Javelosa, M.A.U.; Chua, J.; Bautista, R.; Velez, G.G.B. The effect of Momordica charantia capsule preparation on glycemic control in type 2 diabetes mellitus needs further studies. J. Clin. Epidemiol. 2007, 60, 554-559. [CrossRef]

51. Jiang, B.; Ji, M.; Liu, W.; Chen, L.; Cai, Z.; Zhao, Y.; Bi, X. Antidiabetic activities of a cucurbitane-type triterpenoid compound from Momordica charantia in alloxan-induced diabetic mice. Mol. Med. Rep. 2016, 14, 4865-4872. [CrossRef]

52. Akhtar, N.; Khan, B.A.; Majid, A.; Khan, H.M.S.; Mahmood, T.; Gulfishan; Saeed, T. Pharmaceutical and biopharmaceutical evaluation of extracts from different plant parts of indigenous origin for their hypoglycemic responses in rabbits. Acta Pol. Pharm. 2011, 68, 919-925.

53. Ma, J.; Whittaker, P.; Keller, A.C.; Mazzola, E.P.; Pawar, R.S.; White, K.D.; Callahan, J.H.; Kennelly, E.J.; Krynitsky, A.J.; Rader, J.I. Cucurbitane-type triterpenoids from Momordica charantia. Planta Med. 2010, 76, 1758-1761. [CrossRef]

54. Singh, N.; Gupta, M.; Sirohi, P.; Varsha. Effects of alcoholic extract of Momordica charantia (Linn.) whole fruit powder on the pancreatic islets of alloxan diabetic albino rats. J. Environ. Biol. 2008, 29, 101-106. [PubMed]

55. Singh, N.; Gupta, M. Regeneration of beta cells in islets of Langerhans of pancreas of alloxan diabetic rats by acetone extract of Momordica charantia (Linn.) (bitter gourd) fruits. Indian J. Exp. Biol. 2007, 45, 1055-1062. [PubMed]

56. Mahmoud, M.F.; El Ashry, F.E.; El Maraghy, N.N.; Fahmy, A. Studies on the antidiabetic activities of Momordica charantia fruit juice in streptozotocin-induced diabetic rats. Pharm. Biol. 2017, 55, 758-765. [CrossRef] [PubMed]

57. Kim, K.; Kim, H.Y. Bitter melon (Momordica charantia) extract suppresses cytokine induced activation of MAPK and NF-kB in pancreatic $\beta$-cells. Food Sci. Biotechnol. 2011, 20, 531-535. [CrossRef]

58. Paul, A.; Raychaudhuri, S.S. Medicinal uses and molecular identification of two Momordica charantia varieties-A review. Ej Bio 2010, 6, 43-51. 
59. Poovitha, S.; Parani, M. In Vitro and in Vivo $\alpha$-amylase and $\alpha$-glucosidase Inhibiting Activities of the Protein Extracts from Two Varieties of Bitter Gourd (Momordica Charantia L.). BMC Complement. Altern. Med. 2016, 16, 185. [CrossRef]

60. Attele, A.S.; Zhou, Y.P.; Xie, J.T.; Wu, J.A.; Zhang, L.; Dey, L.; Pugh, W.; Rue, P.A.; Polonsky, K.S.; Yuan, C.-S. Antidiabetic effects of Panax ginseng berry extract and the identification of an effective component. Diabetes 2002, 51, 1851-1858. [CrossRef]

61. Park, J.D.; Rhee, D.K.; Lee, Y.H. Biological Activities and Chemistry of Saponins from Panax ginseng C. A. Meyer. Phytochem. Rev. 2005, 4, 159-175. [CrossRef]

62. Ratan, Z.A.; Haidere, M.F.; Hong, Y.H.; Park, S.H.; Lee, J.-O.; Lee, J.; Cho, J.Y. Pharmacological potential of ginseng and its major component ginsenosides. J. Ginseng Res. 2020. [CrossRef]

63. Konno, C.; Murakami, M.; Oshima, Y.; Hikino, H. Isolation and hypoglycemic activity of panaxans Q, R, S, T and U, glycans of Panax ginseng roots. J. Ethnopharmacol. 1985, 14, 69-74. [CrossRef]

64. Kimura, M.; Waki, I.; Tanaka, O.; Nagai, Y.; Shibata, S. Pharmacological sequential trials for the fractionation of components with hypoglycemic activity in alloxan diabetic mice from ginseng radix. J. Pharmacobiodyn. 1981, 4, 402-409. [CrossRef] [PubMed]

65. Yokozawa, T.; Kobayashi, T.; Oura, H.; Kawashima, Y. Studies on the mechanism of the hypoglycemic activity of ginsenoside-Rb2 in streptozotocin-diabetic rats. Chem. Pharm. Bull. 1985, 33, 869-872. [CrossRef]

66. Kim, H.-J.; Chae, I.-G.; Lee, S.-G.; Jeong, H.-J.; Lee, E.-J.; Lee, I.-S. Effects of Fermented Red Ginseng Extracts on Hyperglycemia in Streptozotocin-induced Diabetic Rats. J. Ginseng Res. 2010, 34, 104-112. [CrossRef]

67. Shao, J.-W.; Jiang, J.-L.; Zou, J.-J.; Yang, M.-Y.; Chen, F.-M.; Zhang, Y.-J.; Jia, L. Therapeutic potential of ginsenosides on diabetes: From hypoglycemic mechanism to clinical trials. J. Funct. Foods 2020, 64, 103630. [CrossRef]

68. Bai, L.; Gao, J.; Wei, F.; Zhao, J.; Wang, D.; Wei, J. Therapeutic Potential of Ginsenosides as an Adjuvant Treatment for Diabetes. Front. Pharmacol. 2018, 9, 423. [CrossRef]

69. Chakrabarti, S.; Sen, S.; Lui, E. Effect of ginseng therapy on diabetes and its chronic complications: Lessons learned. J. Altern. Complement. Med. 2017, 14, 20160166. [CrossRef] [PubMed]

70. Bao, T.T. Effect of total saponin of Panax ginseng on alloxan diabetes in mice. Acta Pharm. Sin. 1981, 16, 618-620.

71. Chen, W.; Balan, P.; Popovich, D.G. Review of Ginseng Anti-diabetic Studies. Molecules 2019, $24,4501$. [CrossRef]

72. Hyun, S.H.; Kim, S.W.; Won, H.; Youn, H.; Kyung, J.S.; Lee, Y.Y.; In, G.; Park, C.-K.; Han, C.-K. Physiological and pharmacological features of the non-saponin components in Korean Red Ginseng. J. Ginseng Res. 2020, 44, 527-537. [CrossRef]

73. Zhou, P.; Xie, W.; He, S.; Sun, Y.; Meng, X.; Sun, G.; Sun, X. Ginsenoside Rb1 as an Anti-Diabetic Agent and Its Underlying Mechanism Analysis. Cells 2019, 8, 204. [CrossRef]

74. World Health Organization. WHO Consultation on Selected Medicinal Plants, 2nd ed.; WHO: Ravello-Salerno, Italy, 1999.

75. Kumari, K.; Mathew, B.C.; Augusti, K.T. Antidiabetic and hypolipidemic effects of S-methyl cysteine sulfoxide isolated from Allium cepa Linn. Indian J. Biochem. Biophys. 1995, 32, 49-54. [PubMed]

76. Lakshmi, M.S.; Rani, K.S.S.; Reddy, U.T.K. A Review on Diabetes Mellitus and the Herbal Plants Used for Its Treatment. Asian J. Pharm. Clin. Res. 2012, 5, 15-21.

77. Galal, E.E.; Gawad, M.A. Antidiabetic activity of Egyptian onion Allium cepa extract. J. Egypt. Med. Assoc. $1965,48,14-45$.

78. Kumari, K.; Augusti, K.T. Antidiabetic and antioxidant effects of S-methyl cysteine sulfoxide isolated from onions (Allium cepa Linn) as compared to standard drugs in alloxan diabetic rats. Indian. J. Exp. Biol. 2002, 40, 1005-1009.

79. Das, S. Garlic-A Natural Source of Cancer Preventive Compounds. Asian Pac. J. Cancer Prev. 2002, 3, $305-311$. [PubMed]

80. Singh, V.; Kumar, R. Study of Phytochemical Analysis and Antioxidant Activity of Allium sativum of Bundelkhand Region. Int. J. Life Sci. Scienti. Res. 2017, 3, 1451-1458. [CrossRef]

81. El-Saber Batiha, G.; Beshbishy, A.M.; Wasef, L.G.; Elewa, Y.H.; Al-Sagan, A.A.; El-Hack, M.E.A.; Taha, A.E.; Abd-Elhakim, Y.M.; Devkota, H.P. Chemical Constituents and Pharmacological Activities of Garlic (Allium sativum L.): A Review. Nutrients 2020, 12, 872. [CrossRef] [PubMed] 
82. Nasir, A.; Fatma, G.; Neshat, N.; Ahmad, M.A. Pharmacological and therapeutic attributes of garlic (Allium sativum Linn.) with special reference to Unani medicine-A review. J. Med. Plants Stud. 2020, 8, 6-9.

83. Chauhan, A.; Sharma, P.K.; Srivastava, P.; Kumar, N. Plants having potential antidiabetic activity: A review. Der. Pharm. Lett. 2010, 2, 369-387.

84. Bnouham, M.; Ziyyat, A.; Mekhfi, H. Medicinal plants with potential antidiabetic activity-a review of ten years of herbal medicine research (1990-2000). Int. J. Diabetes Metab. 2006, 14, 1-25. [CrossRef]

85. Eidi, A.L.; Eidi, M.; Esmaeili, E. Antidiabetic effect of garlic (Allium sativum L.) in normal and streptozotocin-induced diabetic rats. Phytomedicine 2006, 13, 624-629. [CrossRef] [PubMed]

86. Martha, T.; Zainab, A.-A.; Khaled, A.-Q.; Lemia, S.; Muslim, A. Antidiabetic and hypolipidaemic properties of garlic (Allium sativum) in streptozotocin-induced diabetic rats. Int. J. Diabetes Metab. 2007, 15, 108-115.

87. Adinortey, M.B.; Agbeko, R.; Boison, D.; Ekloh, W.; Kuatsienu, L.E.; Biney, E.E.; Kwarteng, J.; Nyarko, A.K. Phytomedicines Used for Diabetes Mellitus in Ghana: A Systematic Search and Review of Preclinical and Clinical Evidence. Evid. Based Complement. Altern. Med. 2019, 6021209. [CrossRef] [PubMed]

88. Ali, A.M. Effect of aloes on blood glucose levels in normal and alloxan diabetic mice. J. Ethnopharmacol. 1990, 28, 215-220.

89. Patel, D.K.; Patel, K.; Dhanabal, S.P. Phytochemical standardization of Aloe vera extract by HPTLC technique. J. Acute Dis. 2012, 47-50. [CrossRef]

90. Yimam, M.; Zhao, J.; Corneliusen, B.; Pantier, M.; Brownell, L.; Jia, Q. Blood glucose lowering activity of aloe based composition, UP780, in alloxan induced insulin dependent mouse diabetes model. Diabetol. Metab. Syndr. 2014, 6, 61. [CrossRef]

91. Kim, K.; Kim, H.; Kwon, J.; Lee, S.; Kong, H.; Im, S.-A.; Lee, Y.-H.; Lee, Y.-R.; Oh, S.-T.; Jo, T.H.; et al. Hypoglycemic and hypolipidemic effects of processed Aloe vera gel in a mouse model of non-insulin-dependent diabetes mellitus. Phytomedicine 2009, 16, 856-863. [CrossRef]

92. Gupta, R.; Gupta, R.S. Effect of Pterocarpus Marsupium In Streptozotocin-Induced Hyperglycemic State In Rats: Comparison With Glibenclamide. Diabetol. Croat. 2009, 38, 39-45.

93. Rahman, M.S.; Mujahid, M.D.; Siddiqui, M.A.; Rahman, M.A.; Arif, M.; Eram, S.; Khan, A.; Azeemuddin, M. Ethnobotanical uses, Phytochemistry and Pharmacological Activities of Pterocarpus marsupium: A review. Pharmacog. J. 2018, 10. [CrossRef]

94. Chakravarthy, B.K.; Gupta, S.; Gambhir, S.S.; Gode, K.D. Pancreatic $\beta$-cell regeneration-A novel anti diabetic mechanism of Pterocarpus marsupium Roxb. Indian J. Pharmacol. 1980, 12, 123-127.

95. Adinarayana, D.; Syamasundar, K.V. A new sesquiterpene alcohol from Pterocarpus marsupium. Phytochemistry 1982, 21, 1083-1085. [CrossRef]

96. Halagappa, K.; Girish, H.N.; Srinivasan, B.P. The study of aqueous extract of Pterocarpus marsupium Roxb. on cytokine TNF- $\alpha$ in type 2 diabetic rats. Indian J. Pharmacol. 2010, 42, 392-396. [CrossRef] [PubMed]

97. Ahmad, F.; Khalid, P.; Khan, M.M.; Rastogi, A.K.; Kidwai, J.R. Insulin like activity in (-) epicatechin. Acta Diabetol. Lat. 1989, 26, 291-300. [CrossRef] [PubMed]

98. Tiwari, P.; Nayak, P.; Prusty, S.K.; Sahu, P.K. Phytochemistry and pharmacology of Tinospora cordifolia: A Review. Syst. Rev. Pharm. 2018, 9, 70-78. [CrossRef]

99. Sharma, P.; Dwivedee, B.P.; Bisht, D.; Dash, A.K.; Kumar, D. The chemical constituents and diverse pharmacological importance of Tinospora cordifolia. Heliyon 2019, 5, e024372. [CrossRef]

100. Kumar, D.V.; Geethanjali, B.; Avinash, K.O.; Kumar, J.R.; Basalingappa, K.M. Tinospora cordifolia: The antimicrobial property of the leaves of amruthaballi. J. Bacteriol. Mycol. Open Access 2017, 5, 363-371. [CrossRef]

101. Rajalakshmi, M.; Anita, R. $\beta$-cell regenerative efficacy of a polysaccharide isolated from methanolic extract of Tinospora cordifolia stem on streptozotocin-indued diabetic Wistae rats. Chem. Biol. Interact. 2016, 243, 45-53. [CrossRef]

102. Sangeetha, M.K.; Balaji Raghavendran, H.R.; Gayathri, V.; Vasanthi, H.R. Tinospora cordifolia attenuates oxidative stress and distorted carbohydrat metabolism in experimentally induced type 2 diabetes in rats. J. Nat. Med. 2011, 65, 544-550. [CrossRef]

103. Patel, M.B.; Mishra, S. Hypoglycemic activity of alkaloidal fraction of Tinospora cordifolia. Phytomedicine 2011, 18, 1045-1052. [CrossRef]

104. Ahmad, W.; Jantan, I.; Bukhari, S.N.A. Tinosporaa crispa (L.) Hook. F. \& Thomson: A Review of Its Ethnobotanical, Phytochemical, and Pharmacological Aspects. Front. Pharmacol. 2016, 7. [CrossRef] 
105. Pathak, A.K.; Jain, D.C.; Sharma, R.P. Chemistry and biological activities of the Genera Tinospora. Pharm. Biol. 1995, 33, 277-287. [CrossRef]

106. Noor, H.; Ashcroft, S.J. Pharmacological characterisation of the antihyperglycaemic properties of Tinospora crispa extract. J. Ethnopharmacol. 1998, 62, 7-13. [CrossRef]

107. Choudhary, M.I.; Ismail, M.; Ali, Z.; Shaari, K.; Lajis, N.H.; Rahman, A. Alkaloidal constituents of Tinospora crispa. Nat. Prod. Commun. 2010, 5, 1747-1750. [CrossRef] [PubMed]

108. Umi Kalsom, Y.; Noor, H. Flavone O-glycosides from Tinospora crispa. Fitoterapia 1995, 66, 280.

109. Koay, Y.C.; Amir, F. A Review of the Secondary Metabolites and Biological Activities of Tinospora crispa (Menispermaceae). Trop. J. Pharm. Res. 2013, 12, 641-649. [CrossRef]

110. Noipha, K.; Ratanachaiyavong, S.; Purintrapiban, J.; Herunsalee, A.; Ninla-aesong, P. Effect of Tinospora crispa on glucose uptake in skeletal muscle: Role of glucose transporter 1 expression and extracellular signal-regulated kinase1/2 activation. Asian Biomed. 2011, 5, 361-369. [CrossRef]

111. Klangjareonchai, T.; Roongpisuthipong, C. The Effect of Tinospora crispa on Serum Glucose and Insulin Levels in Patients with Type 2 Diabetes Mellitus. Hindawi Publ. Corp. J. Biomed. Biotechnol. 2012, 808762. [CrossRef]

112. Tiwari, P.; Mishra, B.N.; Sangwan, N.S. Phytochemical and pharmacological properties of Gymnema sylvestre: An important medicinal plant. BioMed Res. Int. 2014, 2014, 830285. [CrossRef]

113. Khan, F.; Sarker, M.M.R.; Ming, L.C.; Mohamed, I.N.; Zhao, C.; Sheikh, B.Y.; Tsong, H.F.; Rashid, M.A. Comprehensive Review on Phytochemicals, Pharmacological and Clinical Potentials of Gymnema sylvestre. Front. Pharmacol. 2019, 10, 1223. [CrossRef]

114. Sathya, S.; Kokilavani, R.; Gurusamy, K. Hypoglycemic effect of Gymnema sylvestre (retz.,) R.Br leaf in normal and alloxan induced diabetic rats. Anc. Sci. Life 2008, 28, 12-14.

115. Persaud, S.J.; Al-Majed, H.; Raman, A.; Jones, P.M. Gymnema sylvestre stimulates insulin release in vitro by increased membrane permeability. J. Endocrinol. 1999, 163, 207-212. [CrossRef] [PubMed]

116. Ananda, U.; Nandyb, S.; Mundhra, A.; Das, N.; Pandey, D.K.; Dey, A. A review on antimicrobial botanicals, phytochemicals and natural resistance modifying agents from Apocynaceae family: Possible therapeutic approaches against multidrug resistance in pathogenic microorganisms. Drug Resist. Updat. 2020, 51, 100695. [CrossRef] [PubMed]

117. Spasov, A.A.; Samokhina, M.P.; Bulanov, A.E. Antidiabetic properties of Gymnema sylvestre (a review). Pharm. Cham. J. 2008, 42, 626. [CrossRef]

118. Laha, S.; Paul, S. Gymnema sylvestre (Gurmar): A Potent Herb with Anti-Diabetic and Antioxidant Potential. Pharmacog. J. 2019, 11, 201-206. [CrossRef]

119. Sharma, P.; Dubey, G.; Kaushik, S. Chemical and Medico-biological profile of Cyamopsis tetragonoloba (L) Taub: An overview. J. Appl. Pharm. Sci. 2011, 1, 32-37.

120. Rahman, A.U.; Zaman, K. Medicinal plants with hypoglycemic activity. J. Ethnopharmacol. 1989, $26,1-55$. [CrossRef]

121. Hayat, M.; Mukhtar, S.H.; Ansari, Z.A.B.; Naved, T. Antihyperglycemic Activity of Cyamopsis tetragonoloba. Beans on Blood Glucose Levels in Alloxan-Induced Diabetic Rats. Pharm. Biol. 2006, 44, 10-13. [CrossRef]

122. Gandhi, G.R.; Vanlalhruaia, P.; Stalin, A.; Irudayaraj, S.S.; Ignacimuthu, S.; Paulraj, M.G. Polyphenols-rich Cyamopsis tetragonoloba (L.) Taub. beans show hypoglycemic and $\beta$-cells protective effects in type 2 diabetic rats. Food Chem. Toxicol. 2014, 66, 358-365. [CrossRef]

123. Das, S.K.; Vasudevan, D.M. Tulsi: The Indian holy power plant. Nat. Prod. Rad. 2006, 5, 279-283.

124. Verma, S. Chemical constituents and pharmacological action of Ocimum sanctum (Indian holy basil-Tulsi). J. Phytopharmacol. 2016, 5, 205-207.

125. Rahman, S.; Islam, R.; Kamruzzaman, Md.; Alam, M.K. Ocimum sanctum L.: A review of phytochemical and pharmacological profile. Am. Drug Discov. Dev. 2011, 1-15. [CrossRef]

126. Singh, D.; Chaudhuri, P.K. A review on phytochemical and pharmacological properties of Holy basil (Ocimum sanctum L.). Ind. Crops Prod. 2018, 118, 367-382. [CrossRef]

127. Hannan, J.M.; Marenah, L.; Ali, L.; Rokeya, B.; Flatt, P.R.; Abdel-Wahab, Y.H. Ocimum sanctum leaf extracts stimulate insulin secretion from perfused pancreas, isolated islets and clonal pancreatic beta-cells. J. Endocrinol. 2006, 189, 127-136. [CrossRef] [PubMed]

128. Hannan, J.M.A.; Ojo, O.O.; Ali, L.; Rokeya, B.; Khaleque, J.; Akhter, M.; Flatt, P.R.; Abdel-Wahab, Y.H.A. Actions Underlying Antidiabetic Effects of Ocimum sanctum Leaf Extracts in Animal Models of Type 1 and Type 2 Diabetes. Eur. J. Med. Plants 2014, 5, 1-12. [CrossRef] 
129. Patil, R.; Patil, R.; Ahirwar, B.; Ahirwar, D. Isolation and characterization of anti-diabetic component (bioactivity-guided fractionation) from Ocimum sanctum L. (Lamiaceae) aerial part. Asian Pac. J. Trop. Med. 2011, 4, 278-282. [CrossRef]

130. Kapoor, S. Ocimum sanctum: A therapeutic role in diabetes and the metabolic syndrome. Horm. Metab. Res. 2008, 40, 296. [CrossRef]

131. Kim, H.Y.; Sin, S.M.; Lee, S.; Cho, K.M.; Cho, E.J. The Butanol Fraction of Bitter Melon (Momordica charantia) Scavenges Free Radicals and Attenuates Oxidative Stress. Prev. Nutr. Food Sci. 2013, 18, 18-22. [CrossRef]

132. Tsai, T.H.; Huang, C.J.; Wu, W.H.; Huang, W.C.; Chyuan, J.H.; Tsai, P.J. Antioxidant, cell-protective, and anti-melanogenic activities of leaf extracts from wild bitter melon (Momordica charantia Linn. var. abbreviata Ser.) cultivars. Bot. Stud. 2014, 55, 78. [CrossRef]

133. Rathi, S.S.; Grover, J.K.; Vikrant, V.; Biswas, N.R. Prevention of Experimental Diabetic Cataract by Indian Ayurvedic Plant Extracts. Phytother. Res. 2002, 16, 774-777. [CrossRef]

134. Kwon, Y.I.; Apostolidis, E.; Kim, Y.C.; Shetty, K. Health benefits of traditional corn, beans and pumpkin: In vitro studies for hyperglycemia and hypertension management. J. Med. Food 2007, 10, 266-275. [CrossRef]

135. Kazeem, M.I.; Ashafa, A.O.T. In-vitro antioxidant and antidiabetic potentials of Dianthus basuticus Burtt Davy whole plant extract. J. Herb. Med. 2015, 5, 158-164. [CrossRef]

136. Bhutkar, M.; Bhise, S.B. In vitro assay of alpha amylase inhibitory activity of some indigenous plants. Int. J. Chem. Sci. 2012, 10, 457-462. [CrossRef]

137. Mahmood, N. A review of $\alpha$-amylase inhibitors on weight loss and glycemic control in pathological state such as obesity and diabetes. Comp. Clin. Path. 2016, 25, 1253-1264. [CrossRef]

138. de Souza, P.M.; de Oliveira e Magalhães, P. Application of microbial $\alpha$-amylase in industry-A review. Braz. J. Microbiol. 2010, 41, 850-861. [CrossRef] [PubMed]

139. Radha Devi, G.M. A Comprehensive Review On Costus Pictus D. Don. Int. J. Pharm. Sci. Res. 2019, 10, 3187-3195. [CrossRef]

140. Prakash, K.; Harini, H.; Rao, A.; Rao, P.N. A review on Isulin plant (Costus igneus Nak). Pharmacogn. Rev. 2014, 8, 67-72. [CrossRef]

141. Jothivel, N.; Ponnusamy, S.P.; Appachi, M.; Singaravel, S.; Rasilingam, D.; Deivasigamani, K.; Thangavel, S. Anti-diabetic activity of methanol leaf extract of Costus pictus D. Don in alloxan-induced diabetic rats. J. Health Sci. 2007, 53, 655-663. [CrossRef]

142. Peasari, J.R.; Motamarry, S.S.; Varma, K.S.; Anitha, P.; Potti, R.B. Chromatographic analysis of phytochemicals in Costus igneus and computational studies of flavonoids. Inform. Med. Unlocked 2018, 13, 34-40. [CrossRef]

143. Sidhu, A.K.; Wani, S.; Tamboli, P.S.; Patil, S.N. In Vitro Evaluation of Anti-Diabetic Activity of Leaf and Callus Extracts of Costus pictus. Int. J. Recent Sci. Res. 2014, 3, 1622-1625.

144. Jayasri, M.A.; Gunasekaran, S.; Radha, A.; Mathew, T.L. Antidiabetic effect of Costus pictus leaves in normal and streptozotocin-induced diabetes rats. Int. J. Diabetes Metab. 2008, 16, 117-122.

145. Radha, J.M.A.; Mathew, T.L. $\alpha$-amylase and $\alpha$-glucosidase inhibitory activity of Costus pictus D.Don in the Management of diabetes. J. Herb. Med. Toxicol. 2009, 3, 91-94.

146. Ramu, F.A.; Kumar, S.R. Scientific evaluation of traditionally known insulin plant Costus species for the treatment of diabetes in human. Int. J. Curr. Res. Biosci. Plant Biol. 2016, 3, 87-91. [CrossRef]

147. Gireesh, G.; Thomas, S.K.; Joseph, B.; Paulose, C.S. Antihyperglycemic and insulin secretory activity of Costus pictus leaf extract in streptozotocin induced diabetic rats and in in vitro pancreatic islet culture. J. Ethnopharmacol. 2009, 123, 470-474. [CrossRef] [PubMed]

148. Al-Romaiyan, A.; Jayasri, M.A.; Mathew, T.L.; Huang, G.-C.; Amiel, S.; Jones, P.M.; Persaud, S.J. Costus pictus extracts stimulate insulin secretion from mouse and human islets of Langerhans in vitro. Cell Physiol. Biochem. 2010, 26, 1051-1058. [CrossRef]

149. Abu-Reidah, I.M.; Arráez-Román, D.; Lozano-Sánchez, J.; Segura-Carretero, A.; Fernández-Gutiérrez, A. Phytochemical characterisation of green beans (Phaseolus vulgaris L.) by using high-performance liquid chromatography coupled with time-of-flight mass spectrometry. Phytochem. Anal. 2013, 24, 105-116. [CrossRef] [PubMed]

150. Bollini, R.; Chrispeels, M.J. Characterization and subcellular localization of vicilin and phytohemagglutinin, the two major reserve proteins of Phaseolus vulgaris L. Planta 1978, 142, 291-298. [CrossRef]

151. Los, F.G.B.; Zielinski, A.A.F.; Wojeicchowski, J.P.; Nogueira, A.; Demiate, I.M. Beans (Phaseolus vulgaris L.): Whole seeds with complex chemical composition. Curr. Opin. Food Sci. 2018, 19, 63-71. [CrossRef] 
152. Ishimoto, M.; Kitamura, K. Growth inhibitory effects of an alpha-amylase inhibitor from the kidney bean, Phaseolus vulgaris (L.) on three species of Bruchid (Cleoptera: Bruchidae). Appl. Ent. Zool. 1989, 24, 281-286.

153. Ngoh, Y.; Gan, C. Identification of Pinto bean peptides with inhibitory effects on alfa-amylase and angiotensin converting enzyme (ACE) activities using an integrated bioinformatics assisted approach. Food Chem. 2018, 267, 124-131. [CrossRef]

154. Nolan, R.; Shannon, O.M.; Robinson, N.; Joel, A.; Houghton, D.; Malcomson, F.C. It's No Has Bean: A Review of the Effects of White Kidney Bean Extract on Body Composition and Metabolic Health. Nutrients 2020, 12, 1398. [CrossRef]

155. Pueyo', J.J.; Hunt, D.C.; Chrispeels, M.J. Activation of Bean (Phaseolus vulgaris) $\alpha$-Amylase Inhibitor Requires Proteolytic Processing of the Proprotein. Plant Physiol. 1993, 101, 1341-1348. [CrossRef] [PubMed]

156. Barrett, M.L.; Udani, J.K. A proprietary alpha-amylase inhibitor from white bean (Phaseolus vulgaris): A review of clinical studies on weight loss and glycemic control. Nutr. J. 2011, 10-24. [CrossRef] [PubMed]

157. Micheli, L.; Lucarini, E.; Trallori, E.; Avagliano, C.; De Caro, C.; Russo, R.; Calignano, A.; Ghelardini, C.; Pacini, A.; Di Cesare Mannelli, L. Phaseolus vulgaris L. extract: Alpha-amylase Inhibtion against Metabolic Syndrome in Mice. Nutrients 2019, 11, 1778. [CrossRef] [PubMed]

158. Sivaji, A. Euphorbia hirta linn-a review on traditional uses, phytochemistry and pharmacology. World J. Pharm. Res. 2014, 3, 180-205.

159. Widharna, R.M.; Soemardji, A.A.; Wirasutisna, K.R.; Kardono, L.B.S. Anti diabetes mellitus activity in vivo of ethanolic extract and ethyl acetate fraction of Euphorbia hirta L. herb. Int. J. Pharmacol. 2010, 6, 231-240. [CrossRef]

160. Kumar, S.; Malhotra, R.; Kumar, D. Euphorbia hirta: Its chemistry, traditional and medicinal uses, and pharmacological activities. Pharmacogn. Rev. 2010, 4, 58-61. [CrossRef]

161. Tran, N.; Tran, M.; Truong, H.; Le, L. Spray-drying microencapsulation of high concentration of bioactive compounds fragments from Euphorbia hirta L. extract and their effect on diabetes mellitus. Food 2020, 9, 881. [CrossRef]

162. Sheliya, M.A.; Rayhana, B.; Ali, A.; Pillai, K.K.; Aeri, V.; Sharma, M.; Mir, S.R. Inhibition of $\alpha$-glucosidase by new prenylated flavonoids from Euphorbia Hirta, L. herb. J. Ethnopharmacol. 2015, 176, 1-8. [CrossRef]

163. Sheliya, M.A.; Begum, R.; Pillai, K.K.; Aeri, V.; Mir, S.R.; Ali, A.; Sharma, M. In vitro $\alpha$-glucosidase and $\alpha$-amylase inhibition by aqueous, hydroalcoholic, and alcoholic extract of Euphorbia hirta L. Drug Dev. Ther. 2016, 7, 26-30. [CrossRef]

164. Trinh, Q.; Le, L. An investigation of antidiabetic activities of bioactive compounds in Euphorbia hirta Linn using molecular docking and pharmacophore. Med. Chem. Res. 2014, 23, 2033-2045. [CrossRef]

165. Nasry, M.R.; Abo-Youssef, A.M.; Abd El-Latif, H.A. Anti-diabetic activity of the petroleum ether extract of Guar gum in streptozotocin-induced diabetic rats: A comparative study. Beni-Suef Univ. J. Basic Appl. Sci. 2013, 2, 51-59. [CrossRef]

166. Khattab, H.A.; El-Shitany, N.A.; Abdallah, I.Z.; Yousef, F.M.; Alkreathy, H.M. Antihyperglycemic Potential of Grewia asiatica Fruit Extract against Streptozotocin-Induced Hyperglycemia in Rats: Anti-Inflammatory and Antioxidant Mechanisms. Oxid. Med. Cell. Longev. 2015, 549743. [CrossRef]

167. Wei, C.K.; Tsai, Y.H.; Korinek, M.; Hung, P.H.; El-Shazly, M.; Cheng, Y.B.; Wu, Y.C.; Hsieh, T.J.; Chang, F.R. 6-Paradol and 6-Shogaol, the Pungent Compounds of Ginger, Promote Glucose Utilization in Adipocytes and Myotubes, and 6-Paradol Reduces Blood Glucose in High-Fat Diet-Fed Mice. Int. J. Mol. Sci. 2017, 18, 168. [CrossRef] [PubMed]

168. Ali, B.H.; Blunden, G.; Tanira, M.O.; Nemmar, A. Some phytochemical, pharmacological and toxicological properties of ginger (Zingiber officinale Roscoe): A review of recent research. Food Chem. Toxicol. 2008, 46, 409-420. [CrossRef]

169. Imtiyaz, S.; Rahman, K.; Sultana, A.; Tariq, M.; Chaudhary, S.S. Zingiber officinale Rosc.: A traditional herb with medicinal properties. Tang 2013, 3. [CrossRef]

170. Liu, Y.; Liu, J.; Zhang, Y. Research Progress on Chemical Constituents of Zingiber officinale Roscoe. Hindawi BioMed Res. Int. 2019, 5370823. [CrossRef]

171. Sharma, M.; Shukla, S. Hypoglycaemic effect of ginger. J. Res. Indian Yoga Homoeop. 1977, 12, 127-130.

172. Abdulrazaq, N.B.; Cho, M.M.; Win, N.N.; Zaman, R.; Rahman, M.T. Beneficial effects of ginger (Zingiber officinale) on carbohydrate metabolism in streptozotocin-induced diabetic rats. Br. J. Nutr. 2012, 108, 1194-1201. [CrossRef] 
173. Li, Y.; Tran, V.H.; Duke, C.C.; Roufogalis, B.D. Gingerols of Zingiber officinale enhance glucose uptake by increasing cell surface GLUT4 in cultured L6 myotubes. Planta Med. 2012, 78, 1549-1555. [CrossRef]

174. Oboh, G.; Akinyemi, A.J.; Ademiluyi, A.O.; Adefegha, S. Inhibitory effects of aqueous extract of two varieties of ginger on some key enzymes linked to type-2 diabetes in vitro. J. Food Nutr. Res. 2010, 49, 14-20.

175. Akinyemi, A.J.; Ademiluyi, A.O.; Oboh, G. Inhibition of angiotensin-1-converting enzyme activity by two varieties of ginger (Zingiber officinale) in rats fed a high cholesterol diet. J. Med. Food 2014, 17, 317-323. [CrossRef] [PubMed]

176. Sahardi, N.F.N.M.; Makpol, S. Ginger (Zingiber officinale Roscoe) in the Prevention of Ageing and Degenerative Diseases: Review of Current Evidence. Evid. Based Complement. Altern. Med. 2019, 5054395. [CrossRef] [PubMed]

177. Nguyen-Vo, T.-H.; Le, T.; Pham, D.; Nguyen, T.; Le, P.; Nguyen, A.; Nguyen, T.; Nguyen, T.-N.; Nguyen, V.; Do, H.; et al. VIETHERB: A Database for Vietnamese Herbal Species. J. Chem. Inf. Model. 2019, 59, 1-9. [CrossRef]

178. Thanh-Hoang, N.-V.; Loc, N.; Nguyet, D.; Thien-Ngan, N.; Khang, T.; Cao, H.; Le, L. Plant Metabolite Databases: From Herbal Medicines to Modern Drug Discovery. J. Chem. Inf. Model. 2020, 60, 1101-1110.

(C) 2020 by the authors. Licensee MDPI, Basel, Switzerland. This article is an open access article distributed under the terms and conditions of the Creative Commons Attribution (CC BY) license (http://creativecommons.org/licenses/by/4.0/). 